"This is the peer reviewed version of the following article: [Accounting \& Finance, 2016, 56 (3), pp. 627 - 667], which has been published in final form at

[https://onlinelibrary.wiley.com/doi/abs/10.1111/acfi.12093]. This article may be used for non-commercial purposes in accordance with Wiley Terms and Conditions for Self-Archiving." 


\title{
Determinants of the levels and changes in non-executive director compensation
}

\author{
By \\ Martin Bugeja* \\ University of Technology, Sydney \\ Stephanie Fohn \\ University of Technology, Sydney \\ Zoltan Matolcsy \\ University of Technology, Sydney
}

\begin{abstract}
Non-executive director (NED) compensation has not been addressed in detail in prior studies. Accordingly, we examine the economic and director-specific determinants of NED compensation in the Australian setting. We find that NED compensation is associated with: firm size, complexity, growth, risk and liquidity. It is also associated with director reputation, experience, connectedness and the directors' involvement with the firm. The additional compensation paid to the chairperson is positively associated with their prior experience and negatively associated with NED reputation and involvement. We find inconclusive evidence on the association between changes in NED compensation and firm performance.
\end{abstract}

\footnotetext{
* Corresponding author: Martin Bugeja, Accounting Discipline Group, The University of Technology Sydney, 2007, New South Wales, Australia. Telephone + 6129514 3743, fax + 6129514 3669. E-mail address: martin.bugeja@uts.edu.au.

Acknowledgements: The authors acknowledge the comments of Anna Loyeung, Peter Wells, Anna Wright, Neil Fargher (editor), two anonymous reviewers and participants at: the British Accounting and Finance Association Conference (London 2014), the European Accounting Association Annual Meeting (Tallinn 2014) and a research workshop at the University of Technology, Sydney.
} 


\section{Introduction}

The corporate governance literature has extensively examined the influence of board independence on various corporate phenomena. ${ }^{1}$ However, little attention has been given to the compensation of non-executive directors (NEDs). The limited research on NEDs' compensation is U.S. dominated, uses small sample sizes and has primarily focused on firm rather than director-specific characteristics as determinants of NEDs' compensation (Cordeiro, 2000 et al; Ryan Jr and Wiggins III 2004; Yermack 2004). This gap in the literature is curious given that aggregate NED compensation is typically greater than CEO compensation and NEDs often constitute the majority of boards. For example in Australia, the aggregate compensation of NEDs is on average $36 \%$ higher than the CEOs' compensation, ${ }^{2}$ and on average NEDs constitute $67 \%$ of a board (Monem and $\mathrm{Ng}, 2013$ ). Accordingly, the objectives of this study are: i) to provide evidence on the economic and other determinants of the levels and changes in NEDs and chairperson compensation and ii) to examine the association between changes in NEDs' compensation and firm performance.

The motivation for this study is twofold. First, NEDs act as independent representatives of shareholders (Williamson, 1984; Fama and Jensen, 1983) and their primary role is to reduce agency costs by monitoring and advising senior management including the CEO (Fama and Jensen, 1983; Armstrong et al., 2010). Fama and Jensen (1983, p 315) argue, that NEDs are typically 'managers of other corporations and/or important decision agents of other complex organisations' who use their directorships to signal their decision making expertise.

Furthermore, they suggest that this signal is most credible when payments to outside directors are small and directors are motivated to perform their monitoring role by developing a reputation as an effective monitor of management (Masulis and Mobbs, 2014). Directors who build such a reputation are expected to be rewarded with additional future directorships (Fama, 1980).

However, over the last two decades or so, the role of NEDs has substantially changed due to a number of institutional and regulatory changes. First, in the early 2000s many stock

\footnotetext{
${ }^{1}$ Examples include Weisbach, (1988); Rosenstein and Wyatt, (1990); Dechow et al., (1996); Beasley, (1996); Larcker et al., (2007); Masulis et al., (2012).

${ }^{2}$ All Australian compensation and governance data used in this paper are extracted from the Thomson Reuters Connect 4 Boardroom database for the period 2004 to 2012.
} 
exchanges and/or regulators recommended and/or required that the majority of the board of directors be NEDs and that at least the audit committee of the board be made up of NEDs. ${ }^{3}$ Second, in the last two decades in Australia, a number of important court judgements have been handed down which confirm that the fiduciary duties of NEDs are similar to those of executive directors (Lucy 2006). It is our contention, that in today's institutional and regulatory environment, NED compensation does matter and it is driven not only by increased demand for NEDs, but by the expertise and experience of NEDs which allows them to meet their increased obligations. Our argument about the increasing importance of NEDs' compensation is underlined by the observed 63\% increase in median compensation during the period of this study (i.e., 2004-12). Further, the recently introduced 'say on pay' (SOP) legislation in Australia also recognises the importance of NEDs' compensation and enables shareholders to vote both on executive and non-executive directors' compensation (Corporations Amendment Act - For Improving Accountability of Directors and Executive Remuneration, 2011). Accordingly we aim to provide evidence on some of the key determinants of NEDs' compensation in Australia, which may guide firms and compensation committees to develop 'optimal' compensation for NEDs.

The second motivation for this study is to build on and extend earlier U.S. based evidence on NED compensation (Boyd 1996, Bryan, et al., 2000a, Yermack, 2004 and Linn and Park, 2005) to a setting with different governance and institutional features. U.S. research focuses primarily on periods of the 1990s prior to the recent regulatory focus on NEDs. Further, U.S. results may not be applicable to the Australian institutional setting for a number of reasons. First, CEO/Chairman duality in Australia is uncommon and only five percent of our sample combine these roles. This is quite different from the U.S. setting where we estimate that approximately $60 \%$ of boards have CEO and chairperson duality. ${ }^{4}$ In Australia, the chairperson is typically a NED and his/her compensation is on average $36 \%$ of the CEO's compensation. Second, the chairperson, apart from the 'usual' duties of a 'lead' NED, has additional decision rights and responsibilities and is involved in shaping the strategic direction of a firm. For example, the recently appointed non-executive Chair of AMP, Simon McKeon said 'no changes to the company's strategy are required to boost the ugly share price

\footnotetext{
${ }^{3}$ See for example, the Sarbanes-Oxley Act (2002) in the U.S., or the Australian Securities Exchange 2003 Corporate Governance principles and recommendations in Australia.

${ }^{4}$ This statistic is calculated based on data between 2004 and 2012 contained in the Corporate Library database.
} 
performance' (Liew and Pattern 2014). Similarly, Peter Mason, the recently appointed chair of David Jones, has been called upon from shareholders to review Myer’s \$3.2 billion merger proposal as part of the firm's new strategic direction (Mitchell and Spragul 2014). As a result of their additional responsibilities the non-executive chairperson typically receives higher compensation than the other NEDs on the board. Accordingly, we aim to provide evidence on the economic and director-specific determinants of both the level of chairperson's compensation and the premium they are paid beyond other NEDs.

A further institutional difference between the U.S. and Australia is that, there is a nonbinding Australian Securities Exchange (ASX) guidance which recommends against remunerating NEDs based on firm performance. Additionally, the ASX and Productivity Commission guidelines recommend against remunerating NEDs using equity based compensation. As a result, only $25 \%$ of Australian NEDs receive equity based compensation and on average equity compensation is economically insignificant as it represents only $10 \%$ of total NED compensation. In contrast, Yermack (2004) finds that $62 \%$ of U.S. outside director compensation is paid as equity. Consequently, it is questionable as to whether the significant determinants of NED compensation observed in the U.S. also apply in Australia. In addition, due to the infrequent use of equity based compensation it remains an empirical question as to whether there is an association between changes in NEDs' compensation and firm performance. Accordingly, we provide some of this evidence in Australia.

Our evidence is based on a sample of 1,621 ASX listed firms (8,737 firm-years) for the period 2004 to 2012. The mean NED and chairperson total compensation are respectively $\$ 42,404$ and $\$ 83,450 .{ }^{5}$ Our empirical findings indicate that firm characteristics such as firm size and complexity, liquidity and the number of board meetings are positively and significantly associated with NED compensation. Conversely, firm growth and performance are negatively associated with NED compensation. Director-specific characteristics, such as the number of other executive board seats held and the level of involvement within the firm on committees are also found to be associated with higher NED compensation. In contrast, director connectedness results in lower average compensation. We also find that the chairperson premium (i.e., the level of chairperson compensation greater than the average NED compensation) is not associated with a firm's economic characteristics but is instead

\footnotetext{
${ }^{5}$ As a basis of comparison Brick, et al., (2006) reports mean total director compensation of $\$ 67,225$ for their sample of U.S. firms over the period 1992 to 2001.
} 
driven by director-specific characteristics of both the chairperson and other NEDs. For instance, firms with more experienced and involved NEDs pay a lower chairperson premium. In contrast, a chairperson with prior experience as a NED or executive within the same firm is paid a higher premium. Our evidence as to whether NED compensation is positively associated with increases in firm performance produces mixed results. Whilst, we document a significant positive association between increases in NED pay and market returns, we find an insignificant association between return on assets and changes in NED pay.

Our research makes a number of important contributions to the academic literature. First, it confirms that even after two decades of changes to the role and importance of NEDs, their compensation is consistent with firm characteristics which increase the demand for monitoring to reduce agency costs. Second, we add to previous literature and document that individual characteristics of NEDs such as the number of other board seats held, previous experience with the firm and social connectedness are also associated with NEDs' compensation. Finally, we believe that this is the first study which provides insight into some of the key drivers of a non-executive chairperson's compensation and premium.

Our study also contributes to the determination of levels and structure of NEDs' compensation in practice. For example, our results may help the board to explain and justify to shareholders prior to the SOP vote that the level of NED compensation is shaped by firm and director-specific characteristics. Our results may also guide policy makers to reconsider their recommendations with respect to the inclusion of equity based compensation for NEDs, which given the U.S. and our limited evidence may enhance the relations between firm performance and NEDs' compensation.

The remainder of this study is structured as follows. Section 2 describes the setting of NED compensation in the Australian institutional environment. Section 3 outlines prior literature and section 4 describes the economic, director-specific and other determinants that we believe are associated with NED compensation. The sample and descriptive statistics are described in section 5, whilst section 6 provides results. The final section of the paper presents a conclusion and suggestions for future research.

\section{The Institutional Environment}


The Australian institutional environment holds implications for the determination of NED compensation. The Corporations Act 2001 Section 208-211 states that financial benefits paid to a related party (including NEDs) are prohibited unless they are 'reasonable' or approved by shareholders. Compensation that is reasonable is described as being dependent on the circumstances of the company and the responsibilities required by the role. ${ }^{6}$ The board, or in larger firms, the nomination committee, ${ }^{7}$ agrees on the level of the fee pool for the NEDs and chairperson. Once the fee pool has been determined, it must be approved by shareholders. Subsequently, the board (or nomination committee) divides the fee pool between the individual NEDs and the chairperson. Typically each NED receives equal base compensation whilst the chairperson receives a higher level of compensation. However, an individual NED's compensation may be higher than other directors due to their membership on board sub-committees. In 2011, the Australian Government introduced SOP legislation which enables shareholders to vote at the annual general meeting on the compensation awarded to the CEO and executive and non-executive directors. ${ }^{8}$

The Australian Institute of Company Directors (AICD) provides a list of factors which should influence the level of NED compensation. Some factors include the firm's size, nature, profitability and complexity, the industry sector, the risks and challenges faced by the firm and also director experience, time commitment, performance and responsibilities (AICD, 2013). Compensation consultants may also provide guidance in setting NED compensation by supplying benchmark data from companies of a similar industry, size and complexity. ${ }^{9}$ ASX Listing requirement 10.17.2 states that NED compensation should be in the form of a fixed sum (ASX, 2013). Furthermore, NEDs should not receive options and bonus payments (ASX Corporate Governance Principles and Recommendation Guideline 8.2) nor participate in an executive share or option scheme (Productivity Commission, 2009). Directors in Australia also do not receive additional compensation for attending board meetings. The purpose of the guidelines against performance and share based pay of NEDs is to safeguard their independent decision making and to enhance the monitoring of executive management. The lack of performance-based pay of NEDs however conflicts with agency

\footnotetext{
${ }^{6}$ Corporations Act 2001 section 211.

${ }^{7}$ ASX Corporate Governance Principles and Recommendations (Footnote 36 Principle 8) (ASX Corporate Governance Council, 2007).

${ }^{8}$ Corporations Amendment (Improving accountability on director and executive remuneration) Act 2011.

${ }^{9}$ For example, the BHP Billiton 2012 Annual Report states that fees for NEDs are "benchmarked against peer companies with the assistance of externally provided benchmark data" p.157. The Wesfarmers 2012 Annual Report states that fees are "benchmarked against comparable size companies" p.70.
} 
theory, which suggests that compensation should be used to align director and shareholder interests (Cordeiro et al., 2000). Furthermore, Maug (1997) shows analytically that paying directors with shares or options increases their incentive to protect the interest of shareholders. The Australian institutional setting also stands in contrast to the practice in the U.S., where the majority of firms compensate NEDs using incentive structures (Bryan et al., 2000a) including stock options (Fich and Shivdasani, 2005) and meeting attendance fees (Adams and Ferreira, 2008).

\section{Literature Review}

\subsection{Determinants of NED Compensation}

Prior studies examining the determinants of NED compensation focus primarily on firm characteristics which increase the need for monitoring of executive management. For instance, Boyd (1996) finds that NED compensation is positively related to firm size and profitability and consistent with a reduced demand for monitoring reports that NED compensation is negatively related to board equity ownership. Later studies also conclude that determinants of NED compensation are based on the need to reduce agency costs between shareholders and executive management. Specifically, additional determinants include: other sources of external monitoring, investment opportunities, industrial diversification, firm risk and takeover threat (Bryan et al., 2000a; Cordeiro et al., 2000).

More recently, Linn and Park (2005) find that firms with a larger investment opportunity set pay both a higher level of compensation to offset risk exposure and are more likely to use equity-based compensation to improve incentive alignment. They also find a positive association between firm size and NED compensation and conclude that larger firms employ more talented individuals with a higher marginal product. Furthermore, they find that compensation practices used to motivate NEDs are consistent with optimal contracting theory and are thus similar to CEO compensation practices.

The main focus of Brick et al., (2006) is the association between excess director compensation and CEO compensation. They find evidence consistent with cronyism as excessive NED compensation is positively associated with the remuneration paid to the CEO. They model NED compensation as a function of economic and CEO characteristics and report that significant determinants of NED pay include: firm size, complexity and volatility which are positive and significant, while governance characteristics such as CEO-chairperson 
duality, CEO gender and tenure and the number of board meetings are also significant determinants of NED pay.

The evidence in these prior studies is U.S. dominated and is based on early data, small sample sizes and short sample periods. ${ }^{10}$ While the basic theory remains relevant, these factors reduce the ability to generalise the results to the Australian setting. As noted in the introduction the role and prevalence of NEDs has changed significantly over the past decade. ${ }^{11}$ Furthermore, as discussed previously there are a number of important institutional differences between Australia and the U.S.

A number of studies also examine the influence of NED compensation on NED behaviour. Both Adams and Ferreira (2008) and Masulis and Mobbs (2014) find that NEDs' board meeting attendance increases when they are paid a meeting attendance fee. Masulis and Mobbs (2014) also state that in unreported results they find that NEDs are less likely to depart a firm that pays them a higher annual retainer and per meeting fee.

\subsection{Changes in NED Compensation}

Although there is an extensive literature on the pay-performance link of CEO compensation, this area is largely under-researched for NEDs. ${ }^{12}$ Yermack (2004) tests the pay-performance sensitivity of NED compensation in the U.S. and finds that, after controlling for the change in firm size, a positive association exists between market based firm performance and changes in NED compensation. Yermack (2004) also finds that more than half of total NED incentives come from changes in the value of their stock and stock options. Instead of being driven by firm performance, Farrell et al., (2008) find that changes in NED compensation are driven by changes in the market level of NED compensation. Ryan Jr and Wiggins III (2004) find that equity based compensation and board independence are positively associated, thereby suggesting that compensation is more closely aligned to performance when NEDs have greater bargaining power over the CEO. While these U.S. based studies provide

\footnotetext{
${ }^{10}$ Boyd (1996) uses a sample of 92 firms in 1980 and 450 firms in 1987. Cordeiro et al., (2000) uses a sample of 200 U.S. firms in 1996 while Bryan et al., (2000a) uses a sample of 1,700 U.S. firms between 1992 and 1997. Although it presents more contemporary evidence, Linn and Park (2005) lacks generalisability to the Australian setting as it is based on only the 200 largest U.S. corporations between 1996 and 2001.

${ }^{11}$ The introduction of the ASX Corporate Governance Principles and Recommendations in 2003 provided guidelines on board independence and the role of NEDs. Concurrently, the introduction of the Sarbanes Oxley Act in 2002 also increased the importance of NEDs.

12 The pay-performance link for CEO compensation is well documented in the U.S. (Jensen and Murphy 1990; Hall and Liebman, 1998) and in Australia (Clarkson et al., 2011; Matolcsy and Wright, 2011; Matolcsy et al., 2012, Schultz et al., 2013).
} 
evidence of a pay-performance link, it remains unclear as to whether these findings are applicable in the Australian institutional setting. In particular, unlike the U.S., the NEDs of Australian firms do not receive meeting attendance fees and the vast majority do not receive equity-based compensation.

\section{Economic, director-specific and other determinants of NED compensation}

\subsection{The Role of Non-Executive Directors' Compensation}

The primary role of NEDs is to monitor and advise the CEO and other executive directors on behalf of the shareholders and hence minimise agency costs (Fama and Jensen, 1983). An efficient level of compensation should thus provide NEDs with the incentive to perform their monitoring and advising duties. Consequently, the economic characteristics of a firm which determine both the difficulty and the need for monitoring are expected to be associated with the compensation awarded to NEDs.

In addition to reflecting firm characteristics which determine the complexity and necessity of monitoring, the compensation paid to NEDs must also reward them for the skill and expertise they have developed as decision monitors. As such, the level of their compensation must be set to attract and retain talented, experienced and reputable individuals. ${ }^{13}$ For instance, reputable and experienced directors are more inclined to perform their monitoring role and fiduciary duties (Hahn and Lasfer, 2011) to the best of their ability to ensure that their reputation is upheld (Armstrong et al., 2010). In doing so, they also adequately fulfil their role as an agent of shareholders (Shivadasani and Yermack, 1999; Kaufman et al., 2006). Consistent with the above discussion, we expect that NED compensation is a function of both the underlying economic characteristics of the firm (demand side factors) and director characteristics (supply side factors).

\subsection{Determinants of NED Compensation}

\subsubsection{Economic Determinants}

\section{Firm Size and Complexity}

Prior literature on CEO compensation has established that larger firms with more complex operations demand higher quality managers (Rosen, 1982; Smith and Watts, 1992). Using similar reasoning, it is expected that larger, more complex firms require higher quality NEDs

\footnotetext{
${ }^{13}$ As stated in the BHP Billiton Annual Report 2012 "The remuneration rates of NEDs are set at a level which will attract and retain the calibre of directors necessary to contribute to a high performing board " (p. 157).
} 
due to the greater difficulty of monitoring in these firms (Eaton and Rosen, 1983; Brick et al., 2006). An increased difficulty to monitor suggests that NEDs would be expected to commit a greater amount of time and engagement with the firm to gain a sufficient understanding of its activities. Consistent with this argument, larger firms are predicted to be associated with higher NED compensation. ${ }^{14}$ Additionally, it is expected that the NEDs of larger firms experience a greater scope of responsibility and risk exposure to reputation damage and legal liability and must receive higher remuneration to compensate for this additional risk. Consistent with prior literature, size and complexity are proxied for using respectively the natural logarithm of market capitalisation (LnMktCap) and the number of subsidiaries (LnSub) (Linck et al., 2008).

Multi-national diversification also signals greater firm complexity. Bushman et al., (2004) find that geographical diversification leads to complex decision-making and creates a range of monitoring difficulties. It also leads to information asymmetries and complexities resultant of factors such as geographic dispersion, multiple currencies, language, cultural and legal differences (Reeb et al., 1998; Duru and Reeb, 2002; Denis et al., 2003). This increased information asymmetry heightens the engagement required of NEDs in performing their monitoring and advising roles. Therefore, it is expected that geographical diversification results in greater NED compensation. The natural logarithm of the number of foreign subsidiaries is used to measure geographical diversification (LnForSub). ${ }^{15}$

\section{Growth and Investment Opportunities}

Consistent with prior studies on NED and CEO compensation, growth and investment opportunities are included as an economic determinant of compensation (Core et al., 1999; Bryan et al., 2000a; Cordiero et al., 2000; Linn and Park, 2005; Matolcsy and Wright, 2011). High growth firms experience higher information asymmetries as greater firm-specific knowledge is required to take timely advantage of competitive opportunities (Gaver and Gaver, 1993; Smith and Watts, 1992). The NEDs of high growth firms are thus required to expend greater effort in gaining firm specific knowledge and dealing with more frequent and complex issues that arise during times of rapid growth (Cordeiro et al., 2000). This additional effort required by NEDs is consistent with a positive relation to their compensation. Higher

\footnotetext{
14 This determinant is also consistent with benchmarking based on size and complexity performed by compensation consultants.

${ }^{15}$ Business and geographic segments were not used as proxies for size and complexity due to large amounts of missing data. Furthermore, AASB 8 "Operating Segments" introduced on 1 January 2009 requires the reporting of either business or geographic segments, but not both, reducing the reliability of this proxy.
} 
compensation is also required to offset the additional risk associated with high growth firms (Linn and Park, 2005). Furthermore, NEDs are found to add more value when firms have higher investment growth options (Matolcsy et al., 2004). Therefore, firms with more growth options are expected to demand more experienced NEDs and as a result provide them with greater compensation. The market to book ratio $(M T B)$ is used to proxy for growth and investment opportunities (Penman, 1996; Gaver and Gaver, 1993; Matolcsy et al., 2004) Firm Risk/Volatility

Firms experiencing high stock return volatility are more likely to have specific information unknown to outsiders (Jensen, 1983). High information asymmetry increases the difficulty of the monitoring role for NEDs as they must expend both a higher level and more continuous effort to gain a reasonable understanding of a dynamic and highly variable business environment (Brick et al., 2006). High information asymmetry also increases the importance of NEDs due to shareholders and other outsiders having less firm specific information and, therefore, relying more on NEDs to monitor senior management. Because of the greater level of effort required and the increased importance of NEDs, firm risk is expected to be positively associated with NEDs' compensation. Supporting this argument, CEO compensation is found to be higher in firms with greater stock return volatility (Cyert et al.,. 1997). The standard deviation of monthly stock returns (StdRet) is used to proxy for firm risk and volatility (Linck et al., 2008).

\section{Liquidity}

Due to the ASX recommendations that NEDs be compensated with fixed cash compensation, firms experiencing lower levels of liquidity may pay their NEDs less or alternatively resort to equity compensation. Therefore, consistent with Bryan et al., (2000a), it is expected that liquidity is positively associated with NED compensation. The current ratio is used as a measure of firm liquidity (Cur_ratio). In summary, we predict that NED compensation is positively associated with: firm size, complexity, growth, risk and liquidity.

\subsubsection{Director-Specific Determinants}

NED Reputational Capital and Experience

NEDs are often from diverse backgrounds and contribute new expertise, reputational capital and business contacts (Matolcsy et al., 2004). A number of studies document a reputation effect experienced by NEDs with Yermack (2004) and Ferris et al. (2003) showing a positive association between firm performance and the subsequent acquisition of new board seats by 
NEDs (Yermack 2004, Ferris et al., 2003). Fich and Shivdasani (2006) also find that directors holding numerous board seats are more likely to depart a board following poor performance. This study argues that NEDs with more experience and a higher reputation at stake, as measured by the number of other board seats they hold, are better monitors and advisors to senior management. They are expected to be more effective monitors due to their greater level of knowledge and skill arising from their experience and are also more likely to adequately fulfil their duties to protect their reputation (Fama and Jensen, 1983). In terms of strategy, such directors are likely to hold greater accumulated general and industry-specific business knowledge due to their experience in more than one firm (Matolcsy et al., 2004). They are also likely to hold more substantial business networks owing to their reputation and numerous board seats (Matolcsy et al., 2004). Masulis and Mobbs (2011) find evidence that more experienced executives (those holding multiple NED board seats) lead to increased firm performance and growth and more optimal acquisition decisions. Accordingly, NEDs with greater experience and reputational capital are more adequately equipped to perform their role and it is expected that such NEDs demand a greater level of compensation to be attracted to and retained by the firm. The reputation and level of experience of the NEDs are measured at the board level using the average number of external executive board seats (ExecSeats) and external NED board seats (NEDSeats) held on ASX listed companies. ${ }^{16}$

\section{Connectedness of Non-Executive Directors}

Larcker et al., (2013) find that better connected boards have higher firm performance. This improved performance may flow from greater access to information on industry trends, economic conditions and regulation running across the boardroom network. Additionally, a board may be well connected when it is perceived to be powerful and prestigious (Larcker et $a l ., 2013)$. It is expected that a similar phenomenon occurs at the director level, with NEDs being better connected if they hold a board seat which is perceived to be powerful and prestigious. Such NEDs are expected to hold a network of relationships linking them to other highly reputable and connected people and enable them to leverage these connections. Wellconnected NEDs are expected to be aware of their ability to add-value to the firm and use this as leverage to demand greater compensation.

\footnotetext{
${ }^{16}$ Board seats on not for profit entities, trusts and government boards may also proxy for experience and reputation but information on non-ASX directorships is not readily available. We attempt to partially control for these other board seats using our Connectedness variable.
} 
To proxy for the connectedness of NEDs, an indicator variable is used to distinguish firms with at least one board member who is on a connected board (Connectedness). Given that NEDs are often paid equal fixed cash retainers, it is possible that the existence of just one connected NED on the board increases the compensation paid to all NEDs. Connected boards are defined to include those on the Crikey "trophy board" list, ${ }^{17}$ the four largest art galleries in Australia ${ }^{18}$ and the top eight most trusted Australian charities. ${ }^{19}$ "Trophy boards", art galleries and charities are chosen to proxy for prestigious organisations as it is expected that in order to attain a board membership on these organisations a director must have a wellestablished reputation within the corporate community. In addition, board members of charities are often selected for their ability to fundraise and act as a figurehead for the organisation suggesting that this selection criterion is based on a previously established reputation. ${ }^{20}$

\section{Involvement in the Firm}

The ASX Corporate Governance Guidelines recommend that firms establish board subcommittees to deal with specific governance matters (e.g. nomination, remuneration and audit committees) (ASX Corporate Governance Council, 2007). Board sub-committee members are subject to a greater level of responsibility, require greater expertise and also require greater time commitment. Therefore, board sub-committee membership is expected to increase the level of NED compensation. Membership of NEDs on a board committee is proxied for by the average number of committee memberships held by the NEDs (Committees). In summary, we expect that NED compensation is positively associated with:

\footnotetext{
${ }^{17}$ Crikey is an online magazine. It aims to; "to bring its readers the inside word on what's really going on in politics, government, media, business, the arts, sport and other aspects of public life in Australia". The magazine compiles a list of the top 25 "trophy boards." The article states that the "The directors sitting on the nation's notfor-profit "trophy boards" - the 25 or so mostly visual and performing arts jewels that any assiduous networker would give their unvested stock options to join — reads like a who's who of ruling class gatekeepers." Source: http://www.crikey.com.au/2012/10/19/power-and-privilege-the-25-trophy-boards-high-flyers-covet/ Accessed: $7^{\text {th }}$ of November 2013.

18 The four largest art galleries in Australia include the National Gallery of Australia, Art Gallery of New South Wales, National Gallery of Victoria and Museums Board of Victoria (IBISWorld, 2013).

${ }^{19}$ Based on a survey of 1,200 Australians, the top eight most trusted charities include the Salvation Army, The Red Cross, Cancer Council, St Vincent De Paul, RSPCA, World Vision, Guide Dogs, and Royal Children's Hospital (Cavill Societal Marketing and Di Marzio Research, 2011).

${ }^{20}$ We acknowledge that our variable is an imperfect measure of director connectedness across both listed and unlisted boards. The results we find on this variable should therefore be viewed as preliminary evidence on how director connectedness influences NED compensation. Re-estimating our analysis after excluding the Connectedness variable does not change the conclusions from our results.
} 
the number of other board appointments, director connectedness and greater committee membership.

\subsubsection{Other Determinants}

\section{Board Meetings}

As the number of annual board meetings is unregulated in Australia, there is potential for significant variation between firms. This variation provides an indication of the level of engagement required from NEDs in each firm. Firms requiring a greater level of engagement hold more board meetings to boost NEDs' involvement in the firm's decision-making. In order to compensate NEDs for this greater time commitment, the level of compensation is predicted to be positively related to the number of board meetings. As a result, the number of board meetings per year (Meetings) is added to the model of NED compensation. ${ }^{21}$

\section{Substantial Shareholder Ownership}

Prior literature shows that large outside stock holdings facilitate effective monitoring (Bryan et al., 2000b) and ensure that management invest in value-maximising projects (Graves, 1988; Hansen and Hill, 1991; Bushee, 1998). Therefore, outside monitoring is likely to reduce the importance of NEDs in fulfilling their role as agents for shareholders ultimately resulting in lower compensation. Additionally, as NEDs play a highly influential role in determining their own compensation it is possible that they may award themselves excessive compensation (Brick et al.,2006). However, the monitoring of substantial outside shareholders is likely to reduce the ability of NEDs to compensate themselves excessively. Our model tests for the influence on NED compensation of the number of shareholders with over $5 \%$ in firm ownership $(S U B S H) .{ }^{22}$ In summary, we expect that NED compensation is positively associated with: the number of board meetings and negatively associated with the number of substantial shareholders.

\subsubsection{Model of NED compensation}

To test the determinants of NED compensation the following panel regression is estimated:

\footnotetext{
${ }^{21}$ The number of board meetings attended by directors is an alternative measure of the involvement of NEDs with a firm. However, details on board meeting attendance are not electronically available.

${ }^{22}$ Individual shareholdings of NEDs has been considered as a determinant of the level of compensation, however such data is not available in machine readable form and is therefore beyond the scope of this study.
} 
LnComp $=\alpha+\beta_{1}$ LnMktCap $+\beta_{2}$ LnSub $+\beta_{3}$ LnForsub $+\beta_{4}$ MTB $+\beta_{5}$ StdRet $+\beta_{6}$ Cur_ratio $+\beta_{7}$ ExecSeats $+\beta_{8}$ NEDSeats $+\beta_{9}$ Connectedness $+\beta_{10}$ Committees $+\beta_{11}$ Meetings $+\beta_{12}$ SubSH $+\beta_{13}$ IAROA $+\beta_{14}$ DualCEOChair $+\beta_{15}$ BoardComp $+\beta_{16}$ ChairIndicator + Industry + Year $+\varepsilon$

The dependent variable is alternatively measured as the natural logarithm of: combined average compensation of NEDs including the chairperson (LnCOMBComp); average NED compensation excluding the chairperson (LnNEDComp) and chairperson compensation (LnCHAIRComp). ${ }^{23}$ The independent variables are those outlined in the prior sections and remain constant for each model except that the model for the chairperson includes two additional indicator variables highlighting whether the chairperson has prior non-executive (PrNED) or executive (PrNED) experience with the same firm. The model also includes a number of additional control variables. Firm performance is controlled for using industry adjusted return on assets (IAROA) as better performing firms are expected to provide greater compensation to their board members. ${ }^{24}$ Governance controls include board composition (BoardComp) measured as the number of NEDs divided by board size and an indicator variable denoting the presence of a dual CEO/Chairperson (DualCEOChair). In the model using LnCOMBComp as the dependent variable, an additional indicator variable denoting boards with a non-executive chairperson (ChairIndicator) is added as a control. As we are using panel data the models are estimated using fixed effects (grouped by firm) to control for unobservable firm characteristics which may affect the level of NED compensation. ${ }^{25}$ The model also uses robust standard errors clustered by firm to mitigate the existence of heteroskedasticity. ${ }^{26}$ Year and industry indicator variables are included in the model to control for year and industry fixed effects. ${ }^{27}$

\footnotetext{
${ }^{23}$ Each of these measures is calculated using total compensation. The results of robustness testing using cash and equity compensation is reported separately in section 6.5.

${ }^{24}$ The analysis presented in this study is also conducted using unadjusted ROA instead of industry adjusted ROA with no change in results.

${ }^{25}$ The need to use a fixed effects panel regression is confirmed using the findings of a Hausman Test which indicates that a fixed effect model is more appropriate than a random effects model (Greene, 2008).

${ }^{26}$ The White's Test and the Breusch-Pagan Test both confirm the existence of heteroskedasticity.

${ }^{27}$ Industries are defined using two-digit GICS codes.
} 


\subsection{Determinants of the Chairperson Premium}

When the pool of NED compensation is distributed, the chairperson typically receives a premium to compensate them for their increased responsibilities. ${ }^{28} \mathrm{We}$ define the chairperson premium as the difference between the chairperson compensation minus the average NED compensation divided by average NED compensation (CHAIR_Prem). It is expected that many of the economic and director-specific determinants of NED compensation also drive the chairperson premium. However, it is expected that the skills, experience and firm involvement of the NEDs vis-à-vis the chairperson influences the chairperson premium. For example, a board with higher/(lower) calibre NEDs is expected to compensate their chairperson less/(more). This is based on the idea that NEDs are paid more if they are of a higher quality, as the pressure on the chairperson is reduced as he/she is able to rely more on the skill and expertise of the other NEDs. Therefore, it is expected that firms with NEDs that are highly connected, reputable, experienced and more involved in the firm, pay a lower chairperson premium.

We examine the determinants of the chairperson premium by estimating regression model (2). The economic variables are defined in a consistent manner to model (1). The directorspecific variables are separated into unique variables for the chairperson (_CHAIR) and other NEDs (_NED) to allow for a comparison of whether the characteristics of the chairperson and NEDs differ in their effect on the chairperson premium. ${ }^{29}$ Other controls, industry and year indicators are consistent with model (1).

$$
\begin{aligned}
& \text { CHAIR_Prem }=\alpha+\beta_{1} \text { LnMktCap }+\beta_{2} \text { LnSub }+\beta_{3} \text { LnForsub }+\beta_{4} \text { MTB }+\beta_{5} \text { StdRet }+ \\
& \beta_{6} \text { Cur_ratio }+\beta_{7} \text { ExecSeats_NED }+\beta_{8} \text { ExecSeats_CHAIR }+\beta_{9} N E D S e a t s \_N E D+ \\
& \beta_{10} \text { NEDSeats_CHAIR }+\beta_{11} \text { PrNED }+\beta_{12} \text { PrExec }+\beta_{13} \text { Connectedness_NED }+ \\
& \beta_{14} \text { Connectedness_CHAIR }+\beta_{15} \text { Committees_NED }+\beta_{16} \text { Committees_CHAIR }+ \\
& \beta_{17} \text { Meetings }+\beta_{18} \text { SubSH }+\beta_{19} \text { IAROA }+\beta_{20} \text { DualCEOChair }+\beta_{21} \text { BoardComp }+ \text { Industry } \\
& + \text { Year }+\varepsilon
\end{aligned}
$$

\footnotetext{
${ }^{28}$ For example, in 2013, the Wesfarmers (Commonwealth Bank) chairperson was paid $\$ 592,800(\$ 849,800)$ while all other NEDs were paid a base fee of \$197,600 (\$236,400) Source: 2013 Annual Report Commonwealth Bank; 2013 Annual Report Wesfarmers Group.

${ }^{29}$ The Hausman Test reports a significant Chi-squared of 67.08 ( $p$-value $\left.<0.0025\right)$ indicating that fixed effects (grouped by firm) are required in this panel regression model.
} 


\subsection{Changes in NED Compensation}

As discussed in section two regulators in Australia advise against compensating NEDs based on firm performance. However, under agency theory, agency costs are reduced when a strong pay-performance link exists. In addition, U.S. evidence (Yermack, 2004) indicates that most firms compensate their NEDs with equity-based compensation. Therefore, the Australian institutional environment and agency theory present a conflicting expectation as to whether changes in NED compensation are linked with changes in firm performance. We examine the relationship between the change in NED compensation and firm performance using the following regression model: ${ }^{30}$

$\Delta \operatorname{COMP}_{t}=\alpha+\beta_{1} \mathrm{PERF}_{t-1}+\beta_{2} \Delta \operatorname{ASSETS}_{t-1}+$ Industry + Year $+\varepsilon$

The dependent variable is the change in NED compensation measured as the lagged percentage change in average NED compensation. The model is tested using alternate dependent variables for changes in: i) combined NED and chairperson compensation $(\triangle C O M B C O M P)$ ii) average NED compensation $(\triangle N E D C O M P)$ and iii) chairperson compensation $(\triangle C H A I R C O M P)$. Years in which there was a change in the chairperson are excluded from the sample. The first independent variable is firm performance (Perf) measured alternatively as either the annual lagged market-adjusted buy-hold abnormal stock return (MKTADJRET) or the lagged industry-adjusted return on assets (IAROA). ${ }^{31}$ Similar to Yermack (2004), the change in firm size is also included as an independent variable calculated as the lagged percentage change in assets ( $\triangle$ ASSETS). Consistent with the earlier analysis model (3) includes industry and year indicator variables. ${ }^{32}$

Table 1 provides a summary of all variables include in the regression models.

\section{(Insert Table 1 about here)}

\footnotetext{
${ }^{30}$ The aim of this study is to examine whether changes in NED compensation are associated with firm performance. It is beyond the scope of this paper to examine if the improved performance is the outcome of the performance of the NEDs.

${ }^{31}$ Results are qualitatively similar if unadjusted market returns are used.

${ }^{32}$ A Hausman Test indicates that fixed effects (grouped by firm) are most appropriate for the models using $\triangle C O M B C O M P$ and $\triangle N E D C O M P$ as the dependent variable. However, the test indicates that a random effects model is more appropriate for the regression using the change in chairperson compensation as the dependant variable.
} 


\section{Sample and Data}

\subsection{Sample selection}

The evidence in this study is based on a sample of ASX listed firms for the period 2004 to 2012. ${ }^{33}$ Accounting and substantial shareholding ownership data are collected from the Morningstar DatAnalysis database. Stock price information is obtained from the Thomson

Reuters DataStream database. Details on the identity and compensation of directors are

Table 1 Variable names and definitions

\begin{tabular}{|c|c|}
\hline Variable & Definition \\
\hline LnCOMBComp & Natural log of average total compensation paid to NEDs including the chairperson \\
\hline LnNEDComp & $\begin{array}{l}\text { Natural log of average total compensation paid to NEDs excluding the } \\
\text { chairperson }\end{array}$ \\
\hline LnCHAIRComp & Natural log of total compensation paid to the chairperson \\
\hline CHAIR_Prem & $\begin{array}{l}\text { Total chairperson compensation minus total average NED compensation divided } \\
\text { by total average NED compensation }\end{array}$ \\
\hline LnMktCap & Natural log of market capitalisation \\
\hline LnSub & Natural log of the number of subsidiaries \\
\hline LnForSub & Natural log of the number of foreign subsidiaries \\
\hline$M T B$ & Market-to-book ratio \\
\hline StdRet & $\begin{array}{l}\text { Standard deviation of the monthly stock returns over the } 12 \text { months of the current } \\
\text { fiscal year }\end{array}$ \\
\hline Cur_ratio & Current ratio \\
\hline ExecSeats & $\begin{array}{l}\text { Average number of external executive board seats held by NEDs and chairperson } \\
\text { combined }\left(\_C O M B\right) \text { and NEDs only }\left(\_N E D\right) \text {. For the chairperson this variable is } \\
\text { the number of external executive board seats }\left(\_C H A I R\right)\end{array}$ \\
\hline NEDSeats & $\begin{array}{l}\text { Average number of external non-executive board seats held by NEDs and } \\
\text { chairperson combined }\left(\_C O M B\right) \text { and NEDs only }\left(\_N E D\right) \text {. For the chairperson this } \\
\text { variable is the number of external NED board seats }\left(\_C H A I R\right)\end{array}$ \\
\hline Connectedness & $\begin{array}{l}\text { Indicator variable equal to } 1 \text { if the board comprises connected NEDs or } \\
\text { Chairperson }\left(\_C O M B\right) \text {, connected NEDs }\left(\_N E D\right) \text {, connected chairperson } \\
\text { (_CHAIR) and } 0 \text { otherwise }\end{array}$ \\
\hline Committees & $\begin{array}{l}\text { Average number of committee seats held by the NEDs and chairperson combined } \\
\left(\_C O M B\right) \text {, NEDs }\left(\_N E D\right) \text {, chairperson }\left(\_C H A I R\right)\end{array}$ \\
\hline $\operatorname{PrNED}$ & $\begin{array}{l}\text { Indicator variable equal to } 1 \text { if the chairperson was previously a NED within the } \\
\text { firm, and } 0 \text { otherwise }\end{array}$ \\
\hline
\end{tabular}

\footnotetext{
${ }^{33}$ The disclosure requirements for director compensation have primarily remained unchanged over our sample period. In 2004, AASB 1046 "Director and Executive Disclosures by Disclosing Entities" was introduced to require disclosure of the dollar amount of compensation paid to directors separated into four categories: primary benefits; post-employment benefits; equity compensation and other compensation benefits (para. 5.2). Similar disclosure requirements are presently included in AASB 124 "Related Party Disclosures." Prior to 2004, AASB 1017 "Related Party Disclosures" only required disclosure of director compensation for each successive $\$ 10,000$ band of income (para. 4.2).
} 


\begin{tabular}{|l|l|}
\hline PrExec & $\begin{array}{l}\text { Indicator variable equal to } 1 \text { if the chairperson was previously an executive within } \\
\text { the firm, and } 0 \text { otherwise }\end{array}$ \\
\hline Meetings & Number of board meetings held per year \\
\hline SubSh & Number of substantial shareholders \\
\hline IAROA & Industry-adjusted return on assets \\
\hline DualCEOCHAIR & Indicator variable equal to 1 if the CEO is also the chairperson and 0 otherwise \\
\hline BoardComp & Number of NEDs divided by total board size \\
\hline ChairIndicator & Indicator variable equal to 1 if the board has a non-executive chairperson \\
\hline$\triangle$ COMP & Percentage change in total compensation between year $\mathrm{t}$ and year $\mathrm{t}-1$ \\
\hline Perf & Lagged firm performance measured as either MKTAJRET or IAROA $^{-}$ \\
\hline MKTADJRET & Market adjusted buy and hold annual stock return in year $\mathrm{t}-1$ \\
\hline$\triangle A S S E T S$ & Percentage change in assets between year $\mathrm{t}$ and year $\mathrm{t}-1$ \\
\hline
\end{tabular}

collected from the Thomson Reuters Connect4 Boardroom database. As this database simply classifies directors as either executive or non-executive we are unable to further classify directors as grey or independent. Board meetings data is partially obtained from SIRCA Limited and partially hand-collected. Data on whether NEDs hold board seats on connected boards are hand-collected from the respective annual reports. The initial sample of 19,378 firm-years (2,305 firms) from DatAnalysis is reduced to 8,737 (1,621 firms) after deleting firm years with missing data, foreign currency and negative compensation. A breakdown of the sample selection process is provided in Panel A of Table 2.

\section{(Insert Table 2 about here)}

Panel B of Table 2 displays the frequency of firm-years classified by industry for the total sample of combined NED and chairperson compensation and then NED and chairperson subsamples respectively. The number of firm years for the NED compensation sub-sample is 8,509 , while the number of chairperson firm-year observations is 6,505 . The number of chairperson observations is lower as firms with an executive chairperson are excluded from the sample. Firm-years in the materials industry dominate the sample $(48 \%)$, followed by the financial industry $(17 \%)$.

\subsection{Descriptive Statistics}

Table 3 Panel A provides descriptive statistics for the regression variables included in models (1) and (2).

\section{(Insert Table 3 about here)}


The average compensation of NEDs including the chairperson is $\$ 50,212$, while the average NED compensation is $\$ 42,404$ and the average chairperson compensation is $\$ 83,450$. $^{34}$ Furthermore, consistent with prior literature (Matolcsy and Wright, 2011), economic characteristics including market capitalisation, subsidiaries and foreign subsidiaries are transformed into the natural logarithm. Descriptive statistics for the economic determinants are consistent with prior literature. In terms of the director-specific determinants, the average number of external executive board seats (Execseats_Comb) held by the combined sample (including NEDs and the chairperson) is 0.182 , whilst the average number of external NED board seats (NEDseats_Comb) held by the combined sample (including NEDs and the chairperson) is 1.042 . The proportion of boards which are connected is $4.2 \%$, and the number of committee seats held by the combined sample (including NEDs and the chairperson) is on average 1.281. The descriptive statistics also indicate that $18.7 \%(4.6 \%)$ of chairpersons were previously a NED (executive) in the same firm. To reduce the effect of outliers industryadjusted ROA, market adjusted returns and all economic determinants are winsorised at the $5 \%$ level prior to estimating our regression models.

Panel B provides descriptive statistics on the regression variables included in model (3). The average annual change in combined compensation is $29.5 \%$. Interestingly, the average annual change in NED compensation is much larger (32\%) than the average change in chairperson compensation (13\%). The mean market adjusted annual stock return is $8.4 \%$.

In untabulated findings we estimated a Pearson correlation matrix for all variables included in the analyses. The largest correlation which exists between variables in the same regression is that between the number of foreign subsidiaries (LnForSub) and the number of subsidiaries $(\mathrm{LnSub})(0.5793)$. The number of subsidiaries $(\mathrm{LnSub})$ is also correlated with firm size (LnMktCap) (0.5464). The size of the correlations suggest there is no multicollinearity issue with the estimation of the regression models and this is confirmed with VIF diagnostic tests.

\footnotetext{
${ }^{34}$ Cash compensation is on average, $\$ 40,660$ compared to equity, which is on average $\$ 15$. Approximately $25 \%$ of firms remunerate their NEDs with equity.
} 


\section{Results}

\subsection{Determinants of the Level of NED Compensation}

Table 4 reports the results for the analysis of the determinants of the level of compensation using model (1). The dependent variable is alternated between the three measures of compensation, which either include or exclude the chairperson.

\section{(Insert Table 4 about here)}

Column (1) reports the regression results for the combined NED and chairperson sample. The adjusted R-squared is $63.63 \%$ and the F-statistic is 28.62 indicating that the regression is significant at the $1 \%$ level. The R-squared is consistent with those in prior studies of NED compensation using fixed effects models of panel data (Brick et al., 2006). Consistent with prior studies and expectations, firms with greater size and complexity and higher liquidity pay their NEDs more compensation (Bryan et al., 2000a; Brick et al., 2006; Linn and Park, 2005). Inconsistent with expectations and Linn and Park, (2005) firm growth options are negative and significant and firm risk is insignificant. The negative result on firm growth options is unexpected, which may suggest that the proxy is measuring other constructs ${ }^{35}$ or alternatively high growth firms place greater importance on executive directors with greater firm-specific knowledge and, therefore, pay their NEDs less.

In terms of director-specific determinants of compensation, the model shows that reputational capital and experience obtained on other executive board seats are positive and significant. In contrast, NEDs are not paid extra compensation for experience gained as non-executive directors on other boards. The NEDs level of involvement on committees within the firm is positive and significant thereby highlighting that NEDs are compensated for their additional time and responsibility associated with membership on board committees. Surprisingly, the coefficient on connectedness of the board is negative and significant implying that the proxy is inadequate or connected NEDs do not demand greater pay.

Consistent with expectations, a higher number of board meetings results in higher average NED compensation. The number of substantial shareholders however is not a significant determinant indicating that substantial shareholders have little influence over the level of NED

\footnotetext{
35 The market-to-book measure has also been used in other studies as a measure of overvaluation (Bugeja and da Silva Rosa, 2010), conservatism (Wang et al., 2009) and may also indicate that the firm has large off balance sheet intangible assets (Ramanna, 2008).
} 
compensation. The findings on the other control variables are generally consistent with expectations with the exception of accounting-based firm performance, which is negative and significant inconsistent with prior studies (Bryan et al., 2000a; Brick et al., 2006). A possible explanation is that poorly performing firms need to pay NEDs more to entice them to become a member of their board. This result is also consistent with the theory that upholding their reputation is highly important for NEDs. Therefore, by sitting on the board of a poorly performing firm, they are incurring reputation damage and thus require greater compensation. Finally, the chairperson indicator variable is positive and significant, indicating that boards with a non-executive chairperson receive greater average compensation.

Column (2) of Table 4 reports the results for the determinants of average NED compensation excluding the chairperson. The adjusted R-squared is $59.93 \%$ and the F-statistic is 27.25 , showing that the regression is significant at the $1 \%$ level. In this test, the results are similar to that of Column (1) but director connectedness becomes insignificant.

Column (3) of Table reports the determinants of the level of chairperson compensation using equation (1). The adjusted R-squared is $70.04 \%$ and the F-statistic is 16.45 , indicating that the regression is significant at the $1 \%$ level. The findings are similar to column (1) with the exceptions of firm risk, which becomes negative and significant, and liquidity, which becomes insignificant. Contrary to expectations, the results report that high-risk firms pay their chairperson less. A possible explanation is that highly volatile firms place greater importance on executive directors and the CEO who hold more firm-specific knowledge, resulting in lower compensation for the non-executive chairperson. Consistent with an increase in expertise, prior experience within the firm as a NED (PrNED) or executive $($ PrExec) are both a positive and significant determinant of chairperson compensation. In contrast, prior expertise with another firm as either an executive or non-executive director is not associated with chairperson compensation.

To assess the economic significance of our results we calculate the percentage change in compensation for a movement in one standard deviation for each of the variables included in model (1). The data in Table 3 indicates that the average combined and chairperson compensation is $\$ 50,212$ and $\$ 83,450$ respectively. As would be expected the variable which has the largest impact on NED compensation is firm size, with an increase in firm size by one standard deviation implying a rise in combined NED and chairperson compensation of $38 \%$. The variable which has the next largest impact on NED remuneration is committee 
membership. An increase of one standard deviation in committee membership (approximately one committee) raises combined NED and chairperson pay by $10 \%$ and NED (excluding chairperson pay) by $13 \%$. In regards to the other variables which are significantly associated with compensation in Table 4, the change in compensation for a move of one standard deviation ranges between $2 \%$ for the current ratio and $5 \%$ for the market-to-book ratio.

Table 5 reports the results of model (1) estimated separately for each year of the sample. In the interests of brevity the table shows only the results for the combined NED and chairperson sample. ${ }^{36}$

\section{(Insert Table 5 about here)}

The adjusted R-squared ranges between $30.01 \%$ to $43.28 \%$ and the F-statistic ranges from 20.04 to 39.08 , indicating that the regression is significant at the $1 \%$ level. The R-squared is significantly lower than in Table 4 as the model no longer employs a fixed effects panel regression, however, it remains consistent with those in prior studies of NED compensation using a cross-sectional OLS regression (Brick et al., 2006). The findings on the year-by-year results differ slightly from those in Table 4. Interestingly, growth options only seem to influence NED compensation within the later years of the sample. Furthermore, the influence of firm risk is significantly positive from 2009 to 2011 . It is notable that the significance of firm risk coincides with the period of the Global Financial Crisis (GFC) suggesting that during the GFC NEDs were compensated with greater levels of pay for monitoring high risk firms. The significant result on liquidity in Table 4 is non-existent for much of the sample period. Consistent with Table 4, the results indicate that greater director experience and reputation leads to higher compensation (ExecSeats_COMB) with the results being statistically significant from 2007 onwards (other than 2011). Furthermore, connectedness of directors becomes positive and significant from 2009 to 2012 presenting an alternative result to that in Table 4, which was negative and significant. This result suggests that during and after the GFC firms allocated more funds to attracting connected NEDs to perhaps gain access to better information through their director networks (Larcker, et al., 2013).

\footnotetext{
${ }^{36}$ The yearly results for the separate NED and chairperson subsamples are available on request from the corresponding author.
} 
The individual year results for the determinants of the levels of NED and chairperson compensation (untabulated) are largely consistent with the results for the combined chairperson and NED sample provided in Table 5. For NEDs however the year-by-year results show that firm risk has no influence on average NED compensation, whilst director connectedness is a positive and significant determinant of NED compensation in 2010 and 2011 Similar to the combined results, the year-by-year results indicate that firm risk is a positive and significant determinant of chairperson compensation between 2009 and 2011. Additionally, prior NED experience with the same firm results in a significant rise in chairperson compensation only in 2009.

In summary, our results indicate that NED compensation is positively associated with firm economic characteristics particularly firm size and complexity. Unexpectedly firm growth is negatively associated with NED compensation and we find inconsistent evidence on whether firm risk increases or lowers NED remuneration. We also find some evidence that NED compensation is driven by director-specific characteristics. In particular, membership on board sub-committees increases NED compensation. The influence of experience varies between the chairperson and other NEDs. Whilst, other NEDs receive greater compensation for other executive board seats held, the chairperson only receives increased pay for previous experience with the same firm. The results on our connectedness variable are unexpectedly negative in the pooled analysis, although we do find some evidence of a positive effect on compensation in the year-by-year results. We also find that the number of board meetings increases NED compensation consistent with these firms requiring greater involvement of their NEDs. Inconsistent with expectations however, we find that the number of substantial shareholders is negative and insignificant.

\subsection{Determinants of the Chairperson Premium}

Table 6 reports the results for the determinants of the chairperson's premium using equation (2).

\section{(Insert Table 6 about here)}

The adjusted R-squared is $42.08 \%$ and the F-statistic is 4.55 indicating that the regression is significant at the $1 \%$ level. Interestingly, all of the economic determinants (e.g., firm size and complexity, growth options, risk and liquidity) are insignificant in explaining the chairperson premium. The director level characteristics including: other NED board seats, connectedness 
and external experience are all statistically insignificant; however, prior experience by the chairperson with the same firm is positive and significant. This result highlights that firm specific knowledge and tenure within the firm is highly valued and, therefore, leads to a higher chairperson premium. The reputation and external experience of NEDs as executive directors at other firms, as well as the level of NED's involvement in the firm are negative and significant determinants of the chairperson premium. This implies that when the NEDs are highly reputable and experienced and heavily involved in the firm, there is a reduced demand and reliance on the chairperson to perform, therefore, resulting in a lower chairperson premium. Similarly, if the chairperson is highly involved within the firm by participating on a larger number of committees then their premium is greater.

As expected, the coefficient on Meetings is positive and significant indicating that the chairperson premium increases with the number of board meetings in order to compensate the chairperson for their time commitment and involvement in the firm's decision-making.

Substantial shareholding is insignificant, showing that larger shareholders have no influence in determining the chairperson premium. Results on the other control variables are consistent with those found in Table 4. However, board composition is positive and significant suggesting that firms with more independent boards pay a greater chairperson premium. ${ }^{37}$

\subsection{Changes in Compensation and Firm Performance}

Table 7 reports the results for the analysis of the association between changes in NED compensation and alternatively market and accounting based firm performance using Equation (3).

\section{(Insert Table 7 about here)}

Panel A reports the results for the changes in cash compensation. ${ }^{38}$ As the majority of firms in the sample compensate NEDs using only a fixed cash retainer we focus firstly on the change in cash compensation. By using only cash compensation we exclude one-off temporary increases in compensation which may occur when some firms make an equity

\footnotetext{
${ }^{37}$ The descriptive statistics in Table 3 indicate that some firms pay their chairperson less than the average amount paid to NEDs, resulting in a negative chairperson premium. Regression model (2) is re-estimated after excluding these observations and the conclusions from the results are unchanged.

${ }^{38}$ The mean changes in combined cash compensation, NED cash compensation and chairperson cash compensation are $19.7 \% ; 21.4 \%$ and $10.4 \%$, respectively.
} 
grant to the NEDs. This is particularly important given that some equity awards are unusually large. ${ }^{39}$ Columns (1) through (3) report the results using market based performance, whilst columns (4) through (6) use IAROA as the measure of performance. The reported R-squared ranges from $16.43 \%$ to $37.81 \%$ and the F-values and Wald chi-squared are significantly different from zero at the $1 \%$ level. When we use a market-based measure of performance we find a significant positive association between firm performance and all three cash compensation variables (i.e., combined compensation and separate NED and chairperson compensation). This result is similar to the prior evidence found in U.S. studies (Yermack, 2004). In contrast, when model (3) is estimated using IAROA as the performance metric, we find no significant association between the change in compensation and performance. The results also show that the change in firm size is significant and is positively associated with the increase in NED compensation. This shows that the cash retainer paid to NEDs increases as firm size grows and is consistent with pay increasing with higher levels of firm complexity.

Panel B reports the results for the changes in total compensation including both cash and equity components. Once more results are presented using both a market and accounting measure of firm performance. The explanatory power of the regression models is consistent with those in Panel A. Similar to the results for cash compensation we find that the change in total compensation is significantly associated with market adjusted returns but is unrelated to accounting performance. In contrast to the results in Panel A, the change in firm size is only significant in two of the six regression models. Overall, our results therefore provide inconclusive evidence on whether NED compensation is set in order to reduce agency costs and align their interests with those of shareholders.

To assess the economic significance of the results using MKTAJDRET as the performance benchmark, we make use of the results in Panel B of Table 7 and the average compensation statistics presented in Table 3. By extrapolating from this data a $1 \%$ increase in market adjusted returns, results in an annual increase in compensation of: $\$ 45.19$ for the combined NED and chairperson sample; \$37.74 for NEDs (excluding the chairperson) and \$57.50 for the chairperson. Since the average market capitalisation of our sample is $\$ 39.9$ million a $1 \%$ market adjusted return implies an increase in shareholder wealth of $\$ 399,000$. Dividing these

\footnotetext{
${ }^{39}$ Andrew Forrest of Poseidon Nickel Limited was paid \$226,826,000 in options and rights $\$ 8,700,000$ in shares and $\$ 40,000$ in hybrids in the financial year of 2008 .
} 
findings into each other indicates that for each $\$ 1,000$ increment in shareholder wealth NED compensation increases by: $\$ 0.113$ for the combined sample; $\$ 0.094$ for NEDs and $\$ 0.095$ for the chairperson. As a basis of comparison, using the cash retainer paid to outside directors Yermack (2004, p. 2294) reports a similar statistic of \$0.004 for his U.S. sample. The difference between our results and those in Yermack (2004) is possibly explained by the much larger firm size in that study (Yermack, 2004 reports a median sample size of $\$ 6.6$ billion p. 2293).

\subsection{Sensitivity and Additional Testing}

\section{Association between NED and CEO Compensation}

Brick et al., (2006) examine the relationship between excess director compensation and CEO compensation using U.S. data. Consistent with cronyism they find that excess director compensation is associated with higher CEO compensation. As the primary purpose of this study is to examine the determinants of NED compensation we leave it to subsequent research to provide a detailed investigation of the relationship between NED and CEO compensation. ${ }^{40}$ As preliminary evidence however, we calculate the pairwise correlation between total CEO compensation (sourced from the Thomson Reuters Connect4 Boardroom database) and total NED; total chairperson and total combined director compensation. The results (untabulated) indicate that the correlation between total CEO compensation and total NED, total chairperson and total combined compensation are respectively: 0.59, 0.67 and 0.64. Each of the correlations are significant at the $1 \%$ level. As a basis of comparison Brick et al., (2006) report in Table 3 of their study a correlation between total CEO and total director compensation of 0.514. The high positive correlation is not unexpected as the compensation for both CEOs and NEDs are determined by similar economic characteristics. Furthermore, we estimate regression models (1) and (2) with the inclusion of the natural logarithm of CEO compensation as an additional variable ( $L N C E O C O M P)$. We find that $L N C E O C O M P$ is positively related to NED compensation and the chairperson premium. The conclusions drawn from the other variables do not change with the inclusion of CEO compensation in the regression models.

\footnotetext{
40 The lack of electronically available data in Australia on CEO characteristics such as CEO tenure, age, prior experience with the same firm etc. also limits our ability to examine the determinants of CEO compensation.
} 


\section{Cash and Equity Compensation Separately}

The regression results on the determinants of NED compensation presented in Table 4 are based on total compensation paid to NEDs and the chairperson. The regression model is also estimated separately for cash and equity based compensation (results not tabulated). ${ }^{41}$ The results on the determinants of NED cash compensation are largely consistent with those shown in Table 4 with the notable exception of the current ratio, industry-adjusted ROA and the number of board meetings, which are no longer a significant determinant of compensation. Furthermore, consistent with a reputation effect the number of outside NED board seats significantly increases NED compensation.

Consistent with the main results, equity based NED compensation is found to be positively associated with firm size, liquidity, risk and complexity. The positive relationship on risk stands in contrast to the original results. Similar to the main test results, industry-adjusted ROA is negatively associated with equity based compensation. The amount of equity based compensation is not associated with committee membership or outside executive board seats, whilst outside NED experience is negatively related to equity based compensation.

\section{Impact of Firm Size}

To assess if the determinants of NED compensation differ across firm size, the regression analysis is re-estimated after partitioning the sample into firms inside and outside the ASX Top 500 firms by market capitalisation (results not tabulated). The results for firms outside the Top 500 are qualitatively unchanged from those presented. For firms within the Top 500, firm complexity, growth, board connectedness and experience are no longer significant, whilst risk is now negative and significant. The other results remain consistent with those presented. With the chairperson premium results, the results for Top 500 firms are unchanged other than foreign subsidiaries now being negatively related to the chair premium, whilst NED executive seats are now insignificant. For firms outside the Top 500 a number of additional variables attain significance with firm growth and liquidity negatively associated with the chairperson premium.

\section{Differences Across Industry}

\footnotetext{
${ }^{41}$ When equity compensation is used as the dependent variable, a Tobit regression is used due to the high frequency of observations equal to zero. These untabulated results are available on request.
} 
Even though the regression analysis controls for industry fixed effects through the use of indicator variables, we re-run our analysis for total NED compensation after partitioning firms into the financials, mining and other industries (results not tabulated). For firms in other industries the significant determinants of compensation are identical to those in Table 4 except that risk is now negative and significant. The number of significant economic determinants decreases markedly for firms in the financial sector with only size being significant. Director connectedness and reputation remain negatively and positively significant, respectively, whilst industry adjusted ROA is no longer significant. Similar to financials, within the mining sector, the only significant economic determinant is firm size. Director reputation and industryadjusted ROA are respectively positively and negatively related to compensation. The coefficient on director connectedness is insignificant.

The chairperson premium results are largely consistent across industry with the economic determinants continuing to be insignificant. The director characteristics continue to be a significant determinant of the chairperson premium with prior experience within the same firm being positive and significant for the mining and other industries but not financial firms. For financial firms, other board seats held by the chairperson reduce their compensation premium.

\section{Monitoring by Debt Holders and Auditors}

The monitoring role of NEDs may be diminished when the firm uses a high quality auditor or has active monitoring by debt holders (Jensen 1986). Prior findings on leverage are inconclusive, with Brick et al., (2006) reporting that leverage is positively related to NED compensation while Bryan et al., (2000a) find a negative relation. To test the impact of leverage and auditor quality, we add two additional variables to the regression model. The first variable is leverage measured as the ratio of long-term debt divided by total assets. The second variable is an indicator variable highlighting firms which use a Big 4 auditor. The coefficient on leverage is negative and significant only for the combined NED and chairperson compensation sample, but is insignificant in the sub-samples of NED and chairperson compensation. The coefficient on the Big 4 auditor variable is insignificant. The conclusions on the other variables remain unchanged from those in the main results.

\section{Lagged Determinants Model}

Consistent with prior studies (Brick et al., 2006) the model of the determinants of NED compensation is estimated using lagged independent variables. The findings (untabulated) on 
the economic determinants remain largely consistent with those presented except that firm growth and risk are now positively associated with NED and chairperson compensation respectively. The instability of the results on both these variables is similar to the inconsistent findings for growth and risk shown in the yearly regressions in Table 5. As such our study does not provide conclusive evidence on whether growth or risk influences Australian NED compensation. The results for director-specific characteristics, such as reputation and experience, are consistent with the main results. In contrast to the original results, the control variable for performance (i.e., industry-adjusted ROA) is now insignificant.

\section{Which Firms Pay Equity Compensation to NEDs?}

The vast majority of Australian firms do not compensate NEDs with equity-based compensation consistent with the non-binding ASX guidelines. To provide preliminary evidence on the characteristics of firms which choose to pay equity-based compensation, we estimate a logit regression with the dependant variable coded as one for firms paying equity compensation to their NEDs. The independent variables included in the model are the economic characteristics from Model (1). The untabulated results show that firm size, risk, growth and liquidity are positive and significant determinants of the choice to pay equity based compensation. Firm performance is negative and significant, indicating that poorly performing firms are more likely to pay equity based compensation. Interestingly, the number of subsidiaries is negative and significant whilst the number of foreign subsidiaries is positive and significant. This suggests that firms with foreign operations are more likely to pay equity-based compensation perhaps due to other institutional settings (such as the U.S.) not guiding against equity based compensation.

\section{The Impact of the "Two Strikes" Rule}

In 2011, Australia introduced a "two strikes" rule requiring the dissolution of the board of directors (except the CEO) if the remuneration report receives at least a 25 per cent dissent vote in two consecutive years. The introduction of the legislation is consistent with the emerging trend of increasing transparency and accountability of director and executive compensation in many developed countries. ${ }^{42}$ The literature examining the effect of the "two strikes" rule in Australia and SOP legislation in other countries is limited but growing. For

\footnotetext{
${ }^{42}$ The Netherlands, Switzerland, Norway, Sweden, and the United Kingdom all have statute law requiring shareholder votes on executive compensation.
} 
example, Monem and Ng (2013) provides recent Australian evidence that the "two strikes" rule led to an improvement in the CEO pay-performance link. To date there has been no empirical investigation into the impact of the "two strikes" rule on NED compensation. The financial press however suggests that the compensation of the chairperson in the Top 100 ASX firms was cut by $3.5 \%$ in 2012 (Durkin, 2013).

To provide preliminary evidence on the impact (if any) of the "two strikes" rule on NED compensation, Equation (3) is modified to include an indicator variable (POSTTWOSTRIKE) denoting years after the rule came into effect. This indicator variable is also interacted with firm performance to examine if the "two-strikes" rule altered the pay-performance link for NEDs. The results of this regression (untabulated) show that both the POSTTWOSTRIKE indicator variable and the interaction term are insignificant. As such, this preliminary evidence shows the "two-strikes" rule is not associated with changes in NED compensation, nor has it altered the pay-performance link.

\section{Impact of winsorization}

As described in section 5.2 to reduce the effect of outliers industry-adjusted ROA, market adjusted returns and all economic determinants were winsorised at the 5\% level. To examine if winsoring the data has influenced our results, we repeated all of our analysis using the unadjusted data. The conclusions from this additional analysis are largely consistent with those presented in the main tables with the following two exceptions. Using the raw data we find that industry-adjusted ROA is not significantly associated with NED compensation or the chairperson premium. Furthermore, firm risk as measured by the standard deviation of returns is now consistently positive and significant in explaining NED compensation both in aggregate and in the yearly regressions.

\subsection{Limitations}

The evidence presented in the study is limited to compensation and governance data included on the Connect 4 database. As a result, construction of variables such as external executive (ExecSeats) and NED board seats (NEDSeats), as well as whether the chairperson was previously a NED (PrNED) or executive director (PrExec) within the same firm, are limited to details contained within the database. As a result, our measures are likely incomplete. 
Second, there is a lack of readily available data on NED individual shareholdings. As suggested by Core et al., (1999), board ownership characteristics influence the optimal compensation package and it would be expected that NEDs with greater ownership in the firm would require less compensation to align their interests with shareholders. Ideally, board ownership would be included as a determinant of the level of NED compensation.

Third, the proxy used in this study for board connectedness is a preliminary measure. Given that the theory of connected directors is relatively new in the literature (Larcker, et al., 2013), there is no well-established and widely accepted proxy to measure this director characteristic. Furthermore, data on boardroom networks beyond listed firms is not readily available.

\section{Conclusions}

This study examines the economic, director-specific and other determinants of the levels and changes in NED compensation. The findings show that NED compensation is associated with a number of economic characteristics of the firm, as well as characteristics of the NEDs themselves. More specifically, we find that NED compensation is positively associated with firm size and complexity. The influence of growth options on NED compensation is unexpectedly negative, whilst the findings on firm risk and liquidity are inconsistent across our analysis. We show that director-specific determinants also increase NED compensation. In particular, we find for NEDs excluding the chairperson that outside experience as an executive director raises their compensation. In contrast, for the chairperson their compensation increases with experience with the same organisation, rather than experience as a director with other firms. A higher level of involvement of NEDs within the firm on either committees or through a greater number of board meetings leads to higher compensation. We obtain mixed evidence on whether director connectedness increases NED compensation and find that substantial shareholder ownership is not associated with NED remuneration.

We also examine the determinants of the additional pay awarded to the chairperson. Our results show that the additional compensation paid to the chairperson is associated with chairperson characteristics such as whether they have prior experience within the firm or whether they are highly involved in the firm. Furthermore, the chairperson receives less additional pay when the other NEDs are highly involved, reputable and experienced. This suggests that when the board contains high performing NEDs, less importance is placed on the chairperson. 
In regards to changes in NED compensation, our results provide mixed evidence on the existence of a pay-performance relationship. Although we find a positive association between changes in compensation and market returns, our results indicate that changes in pay are not associated with accounting performance. Our results thus suggest that the Australian regulatory advice is possibly successful in restraining the link between NED remuneration and firm performance.

The main contribution of this study is the introduction of director-specific determinants of NED compensation. It would be interesting for future research to extend this aspect of the study by examining how connectedness arises from positions in the public sector/government, social and leisure clubs or from school and university alumni groups. It would also be worthwhile for future research to examine the impact of the levels of NED compensation on director behaviour and economic outcomes. For example, do better compensated NEDs undertake better monitoring and improve mergers and acquisitions outcomes? In addition, while this study examines the association between compensation and average director characteristics measured at the board level, a future study could also examine the association between individual compensation packages and individual director characteristics. Although the NED compensation pool is often distributed evenly between the NEDs, such a study would provide further insight into why some NEDs are paid more than others within the firm. It should be noted that our results are subject to important caveats. In particular, due the Australian institutional environment the general applicability of our findings is primarily limited to settings, where typically the chairperson is not the CEO and where the primary source of compensation of NEDs is based on cash compensation. 


\section{References}

Adams, R. and D, Ferreira, 2008,'Do directors perform for pay?, Journal of Accounting and Economics. 46,. 154-171.

AICD 2013, Determining Directors Fees, viewed 26 August 2013, <www.companydirectors.com.au/Director-Resource-Centre/DirectorQA/Remuneration/Determining-Director-Fees $>$.

Armstrong, C., W. Guay, and J. Weber, 2010, The role of information and financial reporting in corporate governance and debt contracting, Journal of Accounting and Economics $50,179-234$.

Australian Accounting Standards Board, 1997, 'AASB 1017 'Related Party Disclosures', Melbourne, Australia.

Australian Accounting Standards Board, 2004, 'AASB 1046 'Director and Executive Disclosures by Disclosing Entities', Melbourne, Australia.

Australian Accounting Standards Board, 2007, 'AASB 8 'Operating Segments', Melbourne, Australia.

Australian Accounting Standards Board, 2009, 'AASB 124 'Related Party Disclosures', Melbourne, Australia.

ASX 2013, ASX Listing Rules, ASX Limited, viewed 17 November 2013, $<$ http://www.asX.com.au/regulation/rules/asx-listing-rules.htm>.

ASX Corporate Governance Council 2007, Corporate governance principles and recommendations, ASX Corporate Governance Council.

Beasley, M. 1996, An empirical analysis of the relation between the board of director composition and financial statement fraud, The Accounting Review 71, 443-65.

Boyd, B. 1996, Determinants of US outside director compensation, Corporate Governance: An International Review 4, 202-211.

Brick, I., O. Palmon, and J. Wald, 2006, CEO compensation, director compensation, and firm performance: evidence of cronyism?, Journal of Corporate Finance 12, 403-423.

Bryan, S., L. Hwang, A. Klein, and S. Lilien, 2000a, Compensation of outside directors: An empirical analysis of economic determinants, Working Paper, New York University.

Bryan, S., L. Hwang, and S. Lilien, 2000b,'CEO Stock-Based Compensation: An Empirical Analysis of Incentive-Intensity, Relative Mix, and Economic Determinants, The Journal of Business 73, 661-693.

Bugeja, M. and R. da Silva Rosa, 2010, Capital gains taxation and shareholder wealth in takeovers, Accounting and Finance 50,241-262.

Bushee, B. 1998, The influence of institutional investors on myopic RandD investment behavior, The Accounting Review 73, 305-333.

Bushman, R., Q. Chen, E. Engel, and A. Smith, 2004, Financial accounting information, organizational complexity and corporate governance systems, Journal of Accounting and Economics, 37, 167-201.

Cavill Societal Marketing Pty Ltd and Di Marzio Research 2011, 'Australia's most trusted charity', 〈http://www.cavill.com.au/cms/images/10013/trust.pdf $>$.

Clarkson, P., J. Walker, and S. Nicholls, 2011, Disclosure, shareholder oversight and the pay-performance link, Journal of Contemporary Accounting and Economics 7, 47-64.

Cordeiro, J., R. Veliyath, and E. Eramus, 2000, An empirical investigation of the determinants of outside director compensation, Corporate Governance: An International Review 8, 268-279.

Core, J., R. Holthausen, and D. Larcker, 1999, Corporate governance, chief executive officer compensation, and firm performance, Journal of Financial Economics 51, 371-406. 
Cyert, R., S. Kang, P. Kumar, and A. Shah, 1997, Corporate governance, ownership structure, and CEO compensation, Working Paper. Carnegie Mellon University.

Dechow, P. R. Sloan, and A. Sweeney, 1996, Causes and consequences of earnings manipulation: An analysis of firms subject to enforcement actions by the SEC, Contemporary Accounting Research 13, 1-36.

Denis, D. and J. McConnell, 2003, International corporate governance, Journal of Financial and Quantitative Analysis 38, 1-36.

Durkin, P. 2013, Chairmen share CEO pay pain, The Australian Financial Review 26 September 2013, 12.

Duru, A. and D. Reeb, 2002, 'International diversification and analysts' forecast accuracy and bias, The Accounting Review 77, 415-433.

Eaton, J. and H. Rosen, 1983,'Agency, delayed compensation, and the structure of executive remuneration, The Journal of Finance 38, 1489-1506.

Fama, E., 1980. 'Agency problems and the theory of the firm,' The Journal of Political Economy 88, 288-307.

Fama, E. and M. Jensen, 1983, Separation of ownership and control, Journal of Law and Economics 26, 301-325.

Farrell, K., G. Friesen, and P. Hersch, 2008, How do firms adjust director compensation?, Journal of Corporate Finance 14, 153-162.

Ferris, S., M. Jagannathan, and A. Pritchard, 2003, Too busy to mind the business? Monitoring by directors with multiple board appointments, The Journal of Finance $58,1087-1112$.

Fich, E., and A. Shivdasani, 2005, The impact of stock-option compensation for outside directors on firm value, Journal of Business 78, 2229-2254.

Fich, E., and A. Shivdasani, 2006, Are busy boards effective monitors?, The Journal of Finance 61, 689-724.

Gaver, J., and K. Gaver, 1993, Additional evidence on the association between the investment opportunity set and corporate financing, dividend, and compensation policies, Journal of Accounting and Economics 16, 125-160.

Graves, S. 1988, Institutional ownership and corporate R\&D in th computer industry, Academy of Management Journal 31, 417-428.

Greene, W. 2008, Econometric Analysis, 6 edn, Prentice Hall, Upper Saddle River N.J. .

GRG 2008, Remuneration Review: Non-Executive Director Options Opportunity <http://www.godfreyremuneration.com//documents/080822_RR_No_8_Nonexecutive_Director_Options_Opportunity.pdf $>$.

Hahn, P. and M. Lasfer, 2011, The compensation of non-executive directors: rationale, form, and findings, Journal of Management and Governance 15, 589-601.

Hall, B.J. and J. Liebman, 1998, Are CEOs really paid like bureaucrats?, The Quarterly Journal of Economics 113, 653-691.

Hansen, G. and C. Hill, 1991, Are institutional investors myopic? A time-series study of four technology-driven industries, Strategic Management Journal 12, 1-16.

IBIS WORLD 2013, 'Industry Research Reports'.

Jensen, M. and K. Murphy, 1990, Performance pay and top-management incentives, Journal of Political Economy 98, 225-262.

Jensen, M.C. 1983, Organization theory and methodology, The Accounting Review 58, 319339.

Jensen, M. 1986, Agency costs of free cash flow, corporate finance, and takeovers, The American Economic Review 76, 323-329. 
Kaufman, A., E. Englander, and C. Tucci, C. 2006, The Managerial Study Revised: Independent Directors and the CEO'Directorate', Working paper, University of New Hampshire.

Larcker, D., S. Richardson, and I. Tuna, 2007, Corporate governance, accounting outcomes, and organizational performance, The Accounting Review 82, 963-1008.

Larcker, D., E. So, and C. Wang, 2013, Boardroom centrality and firm performance, Journal of Accounting and Economics 55, 225-250.

Liew, R., and S. Pattern, 2014, AMP's new blood likes old strategy, Australian Financial Review 4 March 2014, 15.

Linck, J., J. Netter, and T. Yang, 2008, The determinants of board structure, Journal of Financial Economics 87, 308-328.

Linn, S., and D. Park, 2005, Outside director compensation policy and the investment opportunity set, Journal of Corporate Finance, 680-715.

Lucy, J., 2006, Director's Responsibilities: The reality vs the myths, Australian Institute of Company Directors, Speech to the Australian Institute of Company Directors 17June 2006, available at: http://www.asic.gov.au/asic/pdflib.nsf/LookupByFileName/ Directors_responsibilities_August2006.pdf/\$file/Directors_responsibilities_August20 06.pdf, accessed 20 March, 2014.

Masulis, R., and S. Mobbs, 2011, Are all inside directors the same? Evidence from the external directorship market, The Journal of Finance 66, 823-872.

Masulis, R.and S. Mobbs, 2014, Independent director incentives: Where do talented directors spend their limited time and energy?, Journal of Financial Economics 111, 406-429.

Masulis, R., C. Wang, and F. Xie, 2012, Globalizing the boardroom-The effects of foreign directors on corporate governance and firm performance, Journal of Accounting and Economics 53, 527-554.

Matolcsy, Z., Y. Shan, and V. Seethamraju, 2012, The Timing of Changes in CEO Compensation from Cash Bonus to Equity-based Compensation: Determinants and Performance Consequences, Journal of Contemporary Accounting and Economics 8, 78-91.

Matolcsy, Z., D. Stokes, and A. Wright, A. 2004, Do independent directors add value?, Australian Accounting Review 14, 33-40.

Matolcsy, Z. and A. Wright, 2011, CEO compensation structure and firm performance, Accounting and Finance 51, 745-763.

Maug, E. 1997, Boards of directors and capital structure, Journal of Corporate Finance 3, 113-139.

Mitchell, S., and J. Sprague, 2014, DJs to review Myer merger, Australian Financial Review 19 March 2014, 15.

Monem, R. and C. Ng, 2013, Australia's' Two-Strikes' Rule and the Pay-Performance Link: Are Shareholders Judicious?, Journal of Contemporary Accounting and Economics 9, 237-254.

Penman, S., 1996, The articulation of price-earnings ratios and market-to-book ratios and the evaluation of growth, Journal of Accounting Research 34, 235-259.

Productivity Commission 2009 Executive Remuneration in Australia Report No. 49 Final Enquiry Report Melbourne.

Ramanna, K., 2008, The implications of unverifiable fair-value accounting: Evidence from the political economy of goodwill accounting, Journal of Accounting and Economics 45, 253-281. 
Reeb, D.C. Kwok, and H. Baek, 1998, Systematic risk of the multinational corporation, Journal of International Business Studies 29, 263-279.

Rosen, S. 1982, Contracts and the Market for Executives, National Bureau of Economic Research.

Rosenstein, S. and J. Wyatt, 1990, Outside directors, board independence, and shareholder wealth, Journal of Financial Economics 26, 175-191.

Ryan Jr, H. and R. Wiggins III, 2004, Who is in whose pocket? Director compensation, board independence, and barriers to effective monitoring, Journal of Financial Economics 73, 497-524.

Schultz, E. G. Tian, and G. Twite, 2013, Corporate Governance and the CEO PayPerformance Link: Australian Evidence, International Review of Finance 13, 447472.

Shivdasani, A. and D. Yermack, 1999, CEO involvement in the selection of new board members: An empirical analysis, The Journal of Finance 54, 1829-1853.

Smith, C. and R. Watts, 1992, The investment opportunity set and corporate financing, dividend, and compensation policies, Journal of Financial Economics 32, 263-292.

Weisbach, M. 1988, Outside directors and CEO turnover, Journal of Financial Economics 20, 431-460.

Williamson, O. 1984, Corporate Governance, The Yale Law Journal 93, 1197-1230.

Yermack, D. 2004, Remuneration, Retention, and Reputation Incentives for Outside Directors, The Journal of Finance 59, 2281-2308.

Wang, R., C. hÓgartaigh, and T. van Zijl, 2009, Measures of accounting conservatism: a construct validity perspective, Journal of Accounting Literature 28, 165-203. 
Table 2 Sample Construction

Panel A: Sample Selection (firm-years)

Total ASX listing of from DatAnalysis from 2004 to 2012 (including delisted)

19,378

Deletions:

Missing DatAnalysis data

6,806

Missing Connect4 compensation data

3,482

Firm-years reported in foreign currency

Firm-years reporting negative compensation

344

9

10,641

Total sample size

$\mathbf{8 , 7 3 7}$

\begin{tabular}{|c|c|c|c|c|c|c|c|c|c|c|c|}
\hline \multicolumn{12}{|c|}{ Panel B: Frequency of firm-years by industry } \\
\hline $\begin{array}{l}\text { Industry } \\
\text { (2 digit } \\
\text { GICS) }\end{array}$ & Energy & Materials & Industrials & $\begin{array}{l}\text { Cons. } \\
\text { Disc. }\end{array}$ & $\begin{array}{l}\text { Cons. } \\
\text { staples }\end{array}$ & $\begin{array}{l}\text { Health } \\
\text { Care }\end{array}$ & Financials & I.T. & Telco & Utilities & $\begin{array}{l}\text { Total } \\
\text { firm- } \\
\text { years }\end{array}$ \\
\hline \multirow[t]{2}{*}{ Combined } & 1,320 & 4,183 & 1,250 & 101 & 40 & 91 & 1,476 & 91 & 21 & 164 & 8,737 \\
\hline & $15 \%$ & $48 \%$ & $14 \%$ & $1 \%$ & $1 \%$ & $1 \%$ & $17 \%$ & $1 \%$ & $>1 \%$ & $2 \%$ & $100 \%$ \\
\hline \multirow[t]{2}{*}{ NED } & 1,278 & 4,037 & 1,238 & 99 & 38 & 91 & 1,447 & 91 & 19 & 162 & 8,509 \\
\hline & $15 \%$ & $47 \%$ & $15 \%$ & $1 \%$ & $1 \%$ & $1 \%$ & $17 \%$ & $1 \%$ & $>1 \%$ & $2 \%$ & $100 \%$ \\
\hline \multirow[t]{2}{*}{ Chair } & 972 & 3,078 & 984 & 65 & 31 & 77 & 1,081 & 66 & 13 & 138 & 6,505 \\
\hline & $15 \%$ & $47 \%$ & $15 \%$ & $1 \%$ & $1 \%$ & $1 \%$ & $17 \%$ & $1 \%$ & $>1 \%$ & $2 \%$ & $100 \%$ \\
\hline
\end{tabular}


Table 3 Descriptive statistics

Panel A Compensation and determinants

\begin{tabular}{|c|c|c|c|c|c|c|}
\hline Variable & $\mathrm{N}$ & Mean & Median & Std. Dev. & Min & Max \\
\hline \multicolumn{7}{|l|}{ Compensation variables } \\
\hline LnCOMBCотр & 8,737 & $\begin{array}{c}10.824 \\
(\$ 50,212)\end{array}$ & $\begin{array}{c}10.832 \\
(\$ 50,615)\end{array}$ & $\begin{array}{c}0.870 \\
(\$ 108,316)\end{array}$ & $\begin{array}{l}5.092 \\
(\$ 162)\end{array}$ & $\begin{array}{c}17.916 \\
(\$ 60,369,828)\end{array}$ \\
\hline LnNEDComp & 8,509 & $\begin{array}{c}10.655 \\
(\$ 42,404)\end{array}$ & $\begin{array}{c}10.662 \\
(\$ 42,702)\end{array}$ & $\begin{array}{c}0.881 \\
(\$ 45,488)\end{array}$ & $\begin{array}{l}5.092 \\
(\$ 163)\end{array}$ & $\begin{array}{c}14.500 \\
(\$ 1,982,759)\end{array}$ \\
\hline LnCHAIRComp & 6,505 & $\begin{array}{c}11.332 \\
(\$ 83,450)\end{array}$ & $\begin{array}{c}11.291 \\
(\$ 80,098)\end{array}$ & $\begin{array}{c}0.962 \\
(\$ 51,742)\end{array}$ & $\begin{array}{l}5.106 \\
(\$ 165)\end{array}$ & $\begin{array}{c}19.277 \\
(\$ 235,447,849)^{43}\end{array}$ \\
\hline CHAIR_Prem & 6,646 & 1.150 & 0.827 & 1.526 & -1 & 5.299 \\
\hline \multicolumn{7}{|l|}{ Economic determinants } \\
\hline LnMktCap & 8,737 & $\begin{array}{c}17.502 \\
(\$ 39,904,514)\end{array}$ & $\begin{array}{c}17.193 \\
(\$ 29,297,127)\end{array}$ & $\begin{array}{c}1.988 \\
(\$ 420,058,506)\end{array}$ & $\begin{array}{c}13.91 \\
(\$ 1,099,098)\end{array}$ & $\begin{array}{c}23.163 \\
(\$ 11,469,991,190)\end{array}$ \\
\hline LnSub & 8,737 & $\begin{array}{c}1.674 \\
(5.333)\end{array}$ & $\begin{array}{c}1.386 \\
(3.999)\end{array}$ & $\begin{array}{c}1.083 \\
(2.954)\end{array}$ & $\begin{array}{c}0 \\
(0)\end{array}$ & $\begin{array}{c}6.178 \\
(482.037)\end{array}$ \\
\hline LnForSub & 8,737 & $\begin{array}{c}0.696 \\
(2.006)\end{array}$ & $\begin{array}{c}0 \\
(0)\end{array}$ & $\begin{array}{c}0.990 \\
(2.691)\end{array}$ & $\begin{array}{c}0 \\
(0)\end{array}$ & $\begin{array}{c}5.878 \\
(357.094)\end{array}$ \\
\hline$M T B$ & 8,737 & 2.186 & 1.46 & 1.974 & 0.32 & 7.8 \\
\hline StdRet & 8,737 & 0.190 & 0.170 & 0.108 & 0.044 & 0.446 \\
\hline Cur_Ratio & 8,737 & 8.310 & 3.3 & 11.069 & 0.370 & 41.98 \\
\hline
\end{tabular}

\section{Director-specific}

\section{determinants}

Execseats_COMB

Execseats_NED

Execseats_CHAIR

NEDSeats_COMB

NEDSeats_NED

NEDSeats_CHAIR

Connectedness_COMB

$$
8,737
$$

0.182

8,509

0.211

6,505

0.099

8,737

1.042

8,509

0.900

6,505

1.479

8,737

0.042

Connectedness_NED

8,509

0.033

Connectedness_CHAIR

6,505

0.012

8,737

1.281

Committees_NED

8,509

1.207

Committees_CHAIR

6,505

PrNED

6,505

1.172

0.187

PrExec

6,505

0.046

0
0
0
0.83
0.67
1
0
0
0
1
1
0.5
0
0

0.616

0.797

0.589

0.973

0.967

1.781

0.202

0.180

0.109

1.183

1.145

1.440

0.390

0.209

$\begin{array}{ll}9 & 5.237 \\ 2 & 1.675\end{array}$

$\begin{array}{ll}8,737 & 9.828 \\ 8,737 & 2.219\end{array}$

2.219

1.675

$-0.002$

0.304

$-1.030$

0.211

\section{IAROA}

$\begin{array}{cc}8,737 & -0.108 \\ 8,737 & 0.050\end{array}$

0

0.217

\section{0}

1 ${ }^{43}$ Andrew Forrest of Poseidon Nickel Limited was paid $\$ 226,826,000$ in options and rights $\$ 8,700,000$ in shares and $\$ 40,000$ in hybrids in
the financial year of 2008 . 


\begin{tabular}{|c|c|c|c|c|c|c|}
\hline BoardComp & 8,737 & 0.678 & 0.667 & 0.172 & 0.143 & 1 \\
\hline \multicolumn{7}{|c|}{ Panel B Descriptive statistics for changes in compensation } \\
\hline & & & & Std. & & \\
\hline Variable & $\mathrm{N}$ & Mean & Median & Dev. & Min & $\operatorname{Max}$ \\
\hline$\triangle$ СОМВСотр & 7,114 & 0.295 & 0.025 & 0.883 & -0.683 & 3.005 \\
\hline$\triangle N E D C o m p$ & 6,905 & 0.316 & 0.017 & 0.951 & -0.729 & 3.202 \\
\hline$\triangle C H A I R C O m p$ & 3,309 & 0.128 & 0 & 0.466 & -0.683 & 1.488 \\
\hline MKTADJRET & 7,114 & 0.084 & -0.088 & 0.675 & -0.690 & 1.999 \\
\hline$\triangle A S S E T S$ & 7,114 & 0.342 & 0.087 & 0.805 & -0.533 & 2.856 \\
\hline
\end{tabular}

All variables are defined in Table 1. 


\begin{tabular}{|c|c|c|c|c|}
\hline Dependent Variable & Predicted & $\begin{array}{c}\text { LnCOMBComp } \\
\text { (1) }\end{array}$ & $\begin{array}{c}\text { LnNEDComp } \\
\text { (2) }\end{array}$ & $\begin{array}{c}\text { LnCHAIRComp } \\
\text { (3) }\end{array}$ \\
\hline \multicolumn{5}{|c|}{ Economic determinants } \\
\hline LnMktCap & + & $\begin{array}{c}0.163 * * * \\
(11.68)\end{array}$ & $\begin{array}{c}0.164 * * * \\
(11.33)\end{array}$ & $\begin{array}{l}0.172 * * * \\
\quad(9.41)\end{array}$ \\
\hline $\operatorname{LnSub}$ & + & $\begin{array}{l}0.004 \\
(0.19)\end{array}$ & $\begin{array}{l}-0.000 \\
(-0.01)\end{array}$ & $\begin{array}{l}0.008 \\
(0.37)\end{array}$ \\
\hline LnForSub & + & $\begin{array}{c}0.055 * * * \\
(2.65)\end{array}$ & $\begin{array}{c}0.050 * * \\
(2.26)\end{array}$ & $\begin{array}{c}0.067 * * \\
(2.52)\end{array}$ \\
\hline$M T B$ & + & $\begin{array}{c}-0.018 * * \\
(-2.54)\end{array}$ & $\begin{array}{l}-0.014 * \\
(-1.86)\end{array}$ & $\begin{array}{c}-0.025 * * * \\
(-2.59)\end{array}$ \\
\hline StdRet & + & $\begin{array}{l}-0.134 \\
(-1.33)\end{array}$ & $\begin{array}{l}-0.160 \\
(-1.40)\end{array}$ & $\begin{array}{l}-0.210^{*} \\
(-1.69)\end{array}$ \\
\hline Cur_ratio & + & $\begin{array}{l}0.002 * \\
(1.89)\end{array}$ & $\begin{array}{l}0.002 * \\
(1.89)\end{array}$ & $\begin{array}{l}0.000 \\
(0.32)\end{array}$ \\
\hline \multicolumn{5}{|c|}{ Director specific determinants } \\
\hline ExecSeats & + & $\begin{array}{r}0.045^{*} \\
(1.90)\end{array}$ & $\begin{array}{c}0.049 * * * \\
(2.58)\end{array}$ & $\begin{array}{l}-0.001 \\
(-0.04)\end{array}$ \\
\hline NEDSeats & + & $\begin{array}{l}0.013 \\
(0.94)\end{array}$ & $\begin{array}{l}0.010 \\
(0.63)\end{array}$ & $\begin{array}{l}0.000 \\
(0.01)\end{array}$ \\
\hline Connectedness & + & $\begin{array}{c}-0.126^{* *} \\
(-2.15)\end{array}$ & $\begin{array}{l}-0.074 \\
(-1.20)\end{array}$ & $\begin{array}{l}-0.016 \\
(-0.20)\end{array}$ \\
\hline $\operatorname{PrNED}$ & + & - & - & $\begin{array}{l}0.041^{*} \\
(1.68)\end{array}$ \\
\hline PrExec & + & - & - & $\begin{array}{c}0.192 * * \\
(2.42)\end{array}$ \\
\hline Committees & + & $\begin{array}{c}0.083 * * * \\
(5.77)\end{array}$ & $\begin{array}{c}0.112 * * * \\
\quad(7.76)\end{array}$ & $\begin{array}{c}0.023 * * \\
(2.04)\end{array}$ \\
\hline \multicolumn{5}{|l|}{ Other determinants } \\
\hline Meetings & + & $\begin{array}{c}0.005 * * \\
(2.31)\end{array}$ & $\begin{array}{l}0.005^{*} \\
(1.92)\end{array}$ & $\begin{array}{c}0.006 * * \\
(2.21)\end{array}$ \\
\hline SubSH & - & $\begin{array}{l}-0.006 \\
(-1.01)\end{array}$ & $\begin{array}{l}-0.010 \\
(-1.45)\end{array}$ & $\begin{array}{l}0.003 \\
(0.31)\end{array}$ \\
\hline \multicolumn{5}{|c|}{ Other control variables } \\
\hline IAROA & + & $\begin{array}{c}-0.236^{* * * *} \\
(-4.92)\end{array}$ & $\begin{array}{c}-0.196^{* * * *} \\
(-4.02)\end{array}$ & $\begin{array}{c}-0.316^{* * * *} \\
(-5.10)\end{array}$ \\
\hline DualCEOChair & - & $\begin{array}{c}-0.123 * * \\
(-1.97)\end{array}$ & $\begin{array}{l}-0.057 \\
(-0.85)\end{array}$ & $\begin{array}{l}-0.095 \\
(-0.73)\end{array}$ \\
\hline BoardComp & - & $\begin{array}{c}-0.428 * * * \\
(-5.12)\end{array}$ & $\begin{array}{c}-0.444 * * * \\
(-4.80)\end{array}$ & $\begin{array}{l}-0.062 \\
(-0.58)\end{array}$ \\
\hline ChairIndicator & + & $\begin{array}{c}0.117 * * * \\
(2.71)\end{array}$ & - & - \\
\hline Constant & & $\begin{array}{c}7.496 * * * \\
(25.59) \\
\end{array}$ & $\begin{array}{c}7.272 * * * \\
(24.24)\end{array}$ & $\begin{array}{c}8.089 * * * \\
(18.01)\end{array}$ \\
\hline Firm years (firms) & & $8,737(1,621)$ & $8,509(1,607)$ & $6,505(1,397)$ \\
\hline Adjusted R-Squared & & 0.6363 & 0.5993 & 0.7004 \\
\hline F Value & & $28.62 * * *$ & $27.25 * * *$ & $16.45 * * *$ \\
\hline $\begin{array}{l}\text { This table presents fix } \\
\text { compensation on vario } \\
\text { and industry indicator } \\
\text { variables are defined } \\
\text { confidence levels. }\end{array}$ & $\begin{array}{l}\text { panel regres } \\
\text { nic, director- } \\
\text { Standard er } \\
\text { The supersc }\end{array}$ & $\begin{array}{l}\text { ns (grouped by fir } \\
\text { ecific and other de } \\
\text { rs are clustered by } \\
\text { pts } * * *, * * \text {, and } *\end{array}$ & $\begin{array}{l}\text { NED, chairper } \\
\text { inants. The regr } \\
\text { and adjusted for } \\
\text { ate significance }\end{array}$ & $\begin{array}{l}\text { nd combined } \\
\text { ns include year } \\
\text { roskedasticity. All } \\
1 \%, 5 \% \text { and } 10 \%\end{array}$ \\
\hline
\end{tabular}


Table 5 OLS regression for the determinants of combined compensation (LnCOMBComp) by year

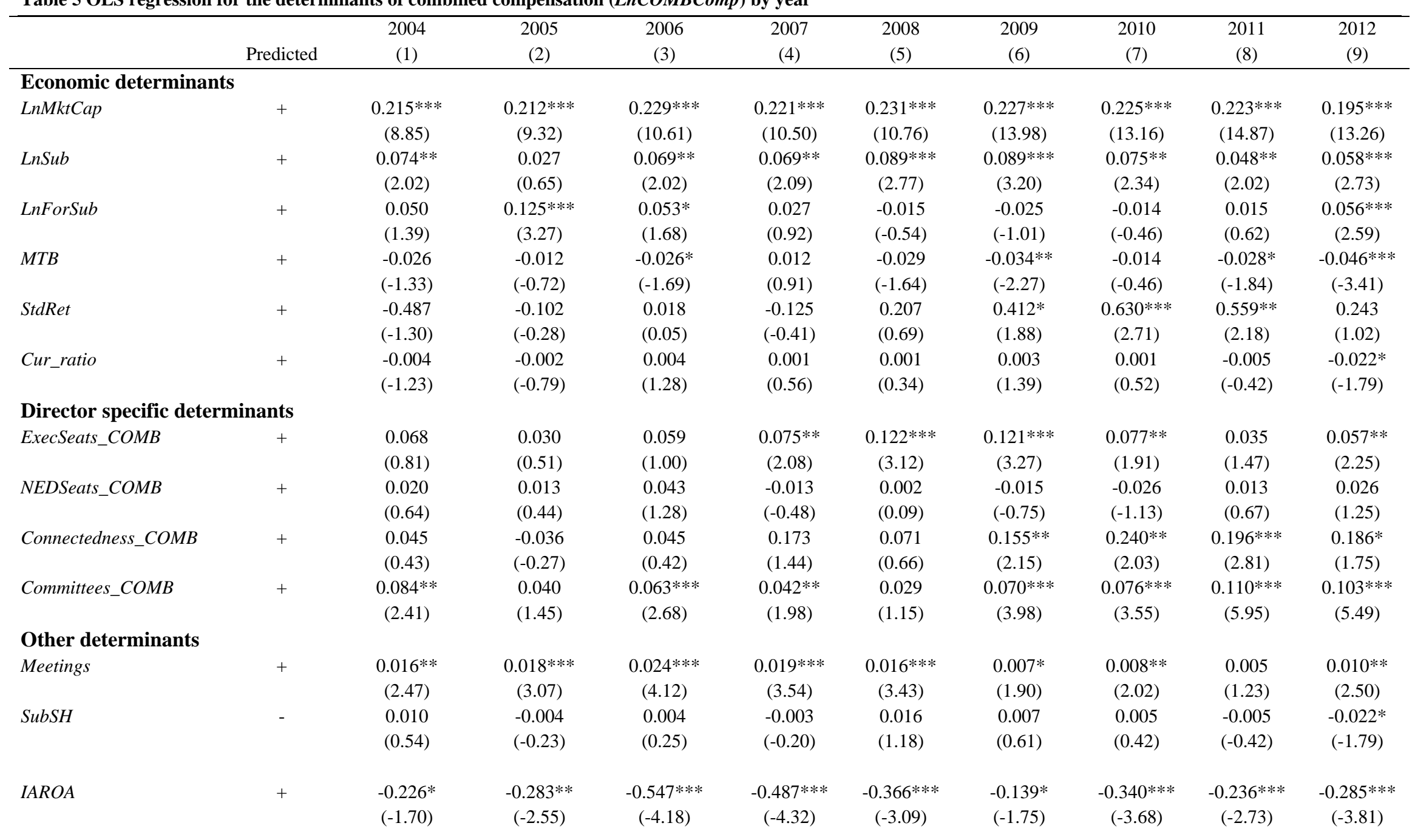




\begin{tabular}{|c|c|c|c|c|c|c|c|c|c|c|}
\hline \multicolumn{11}{|l|}{$\begin{array}{l}\text { Other control } \\
\text { variables }\end{array}$} \\
\hline DualCEOChair & - & $\begin{array}{l}-0.336^{*} \\
(-1.90)\end{array}$ & $\begin{array}{l}-0.180 \\
(-1.58)\end{array}$ & $\begin{array}{c}-0.228^{*} \\
(-1.71)\end{array}$ & $\begin{array}{c}-0.348 * * * \\
(-3.54)\end{array}$ & $\begin{array}{l}-0.131 \\
(-1.22)\end{array}$ & $\begin{array}{c}-0.255^{* *} \\
(-2.35)\end{array}$ & $\begin{array}{c}-0.219 * * \\
(-2.07)\end{array}$ & $\begin{array}{c}-0.286^{* *} \\
(-2.37)\end{array}$ & $\begin{array}{l}-0.087 \\
(-0.80)\end{array}$ \\
\hline BoardComp & - & $\begin{array}{c}-0.567 * * * \\
(-2.63)\end{array}$ & $\begin{array}{c}-0.520 * * * \\
(-3.14)\end{array}$ & $\begin{array}{c}-0.397 * * \\
(-2.05)\end{array}$ & $\begin{array}{c}-0.559 * * * \\
(-3.57)\end{array}$ & $\begin{array}{c}-0.391 * * \\
(-2.54)\end{array}$ & $\begin{array}{c}-0.617 * * * \\
(-4.97)\end{array}$ & $\begin{array}{c}-0.507 * * * \\
(-3.78)\end{array}$ & $\begin{array}{c}-0.437 * * * \\
(-3.34)\end{array}$ & $\begin{array}{c}-0.442 * * * \\
(-3.58)\end{array}$ \\
\hline ChairIndicator & + & $\begin{array}{c}0.254 * * * \\
(2.86)\end{array}$ & $\begin{array}{c}0.190 * * * \\
(2.62)\end{array}$ & $\begin{array}{c}0.164 * * \\
(2.07)\end{array}$ & $\begin{array}{c}0.165^{* *} \\
(2.40)\end{array}$ & $\begin{array}{c}0.150 * * \\
(2.24)\end{array}$ & $\begin{array}{c}0.152 * * * \\
(2.80)\end{array}$ & $\begin{array}{c}0.138^{* *} \\
(2.35)\end{array}$ & $\begin{array}{c}0.136^{* *} \\
(2.28)\end{array}$ & $\begin{array}{c}0.183^{* * * *} \\
(3.40)\end{array}$ \\
\hline Constant & & $\begin{array}{c}6.486 * * * \\
(13.12)\end{array}$ & $\begin{array}{c}5.403 * * * \\
(11.58)\end{array}$ & $\begin{array}{c}5.833 * * * \\
(11.98)\end{array}$ & $\begin{array}{c}5.885^{* * *} \\
(9.94)\end{array}$ & $\begin{array}{c}6.857 * * * \\
(10.07)\end{array}$ & $\begin{array}{c}6.787 \\
(22.71)\end{array}$ & $\begin{array}{c}7.280 * * * \\
(9.52)\end{array}$ & $\begin{array}{c}6.680 * * * \\
(19.91)\end{array}$ & $\begin{array}{c}7.159 * * * \\
(13.99)\end{array}$ \\
\hline Firm & & 603 & 680 & 800 & 945 & 1,115 & 1,138 & 1,095 & 1,191 & 1,170 \\
\hline Adjusted R-Squared & & 0.4328 & 0.4122 & 0.3786 & 0.3868 & 0.3001 & 0.4104 & 0.3183 & 0.3617 & 0.3536 \\
\hline F Value & & $23.30 * * *$ & $20.04 * * *$ & $23.31 * * *$ & $26.41 * * *$ & $27.72 * * *$ & $39.08 * * *$ & $21.43 * * *$ & $37.93 * * *$ & $26.10 * * *$ \\
\hline
\end{tabular}

This table presents OLS regressions of combined NED and chairperson compensation on various economic, director-specific and other determinants separately for each year of our sample. The regressions include industry indicator variables and standard errors are adjusted for heteroskedasticity. All variables are defined in Table 1.

The superscripts $* * *, * *$, and $*$ indicate significance at the $1 \%, 5 \%$ and $10 \%$ confidence levels. 
Table 6 Panel regression for the determinants of the premium in chairperson compensation

\begin{tabular}{|c|c|c|c|}
\hline Variable & Predicted & Coefficient & $t$-stat \\
\hline \multicolumn{4}{|l|}{ Economic determinants } \\
\hline LnMktCap & + & 0.023 & 0.65 \\
\hline LnSub & + & 0.049 & 0.94 \\
\hline LnForSub & + & -0.063 & -1.15 \\
\hline$M T B$ & + & -0.016 & -0.86 \\
\hline StdRet & + & 0.397 & 1.49 \\
\hline Cur_ratio & + & -0.002 & -0.78 \\
\hline \multicolumn{3}{|l|}{ Director specific } & \\
\hline ExecSeats_NED & - & $-0.075^{*}$ & -1.69 \\
\hline ExecSeats_CHAIR & + & 0.121 & 1.47 \\
\hline NEDSeats_NED & - & -0.039 & -0.95 \\
\hline NEDSeats_CHAIR & + & -0.002 & -0.09 \\
\hline $\operatorname{PrNED}$ & + & $0.203 * * *$ & 3.30 \\
\hline PrExec & + & $0.666 * * *$ & 3.91 \\
\hline Connectedness_NED & - & 0.052 & 0.30 \\
\hline Connectedness_CHAIR & + & -0.077 & -0.29 \\
\hline Committees_NED & - & $-0.287 * * *$ & -7.66 \\
\hline Committees_CHAIR & + & $0.105 * * *$ & 4.22 \\
\hline \multicolumn{4}{|l|}{ Other determinants } \\
\hline Meetings & + & $0.013 * *$ & 2.26 \\
\hline SubSH & - & 0.024 & 1.43 \\
\hline \multicolumn{4}{|l|}{ Other control variables } \\
\hline IAROA & + & $-0.313 * * *$ & -2.75 \\
\hline DualCEOChair & + & -0.104 & -0.43 \\
\hline BoardComp & - & $1.066 * * *$ & 4.51 \\
\hline Constant & & 0.106 & 0.12 \\
\hline Firm years (firms) & & $6,646(1,424)$ & \\
\hline Adjusted R-squared & & 0.4208 & \\
\hline F Value & & $4.55 * * *$ & \\
\hline
\end{tabular}

This table presents a fixed effects panel regression (grouped by firm) of the premium paid to the chairperson on various economic, director-specific and other determinants. The regressions include year and industry dummies and are estimated. Standard errors are clustered by firm. All variables are defined in Table 1. The superscripts ***, **, and * indicate significance at the $1 \%, 5 \%$ and $10 \%$ confidence levels. 
Table 7 Panel regression of changes in compensation

\begin{tabular}{|c|c|c|c|c|c|c|c|}
\hline \multicolumn{8}{|c|}{ Panel A Changes in cash compensation } \\
\hline Dependent variable & Predicted & $\begin{array}{c}\triangle \mathrm{COMB} \\
\text { CASHCOMP } \\
(1)\end{array}$ & $\begin{array}{c}\triangle \mathrm{NED} \\
\text { CASHCOMP } \\
(2)\end{array}$ & $\begin{array}{c}\triangle \mathrm{CHAIR} \\
\text { CASHCOMP } \\
\text { (3) }\end{array}$ & $\begin{array}{c}\triangle \mathrm{COMB} \\
\text { CASHCOMP } \\
(4)\end{array}$ & $\begin{array}{c}\triangle \mathrm{NED} \\
\text { CASHCOMP } \\
(5)\end{array}$ & $\begin{array}{c}\Delta \text { CHAIR } \\
\text { CASHCOMP } \\
(6)\end{array}$ \\
\hline MKTADJRET $_{t-1}$ & $?$ & $\begin{array}{c}0.053 * * * \\
(3.43)\end{array}$ & $\begin{array}{c}0.057 * * * \\
(3.13)\end{array}$ & $\begin{array}{c}0.045 * * * \\
(5.81)\end{array}$ & - & - & - \\
\hline IAROA $_{t-1}$ & $?$ & - & - & - & $\begin{array}{l}-0.019 \\
(-0.38)\end{array}$ & $\begin{array}{l}-0.010 \\
(-0.17)\end{array}$ & $\begin{array}{l}-0.007 \\
(-0.36)\end{array}$ \\
\hline$\Delta \operatorname{ASSETS}_{t-1}$ & + & $\begin{array}{c}0.042 * * * \\
(3.00)\end{array}$ & $\begin{array}{c}0.052 * * * \\
(3.23)\end{array}$ & $\begin{array}{c}0.020 * * * \\
(2.93)\end{array}$ & $\begin{array}{c}0.058 * * * \\
(4.02)\end{array}$ & $\begin{array}{c}0.068 * * * \\
(4.21)\end{array}$ & $\begin{array}{c}0.033 * * * \\
(4.85)\end{array}$ \\
\hline Constant & & $\begin{array}{l}-0.056 \\
(-0.16)\end{array}$ & $\begin{array}{l}0.044 \\
(0.11)\end{array}$ & $\begin{array}{l}-0.199 \\
(-1.41)\end{array}$ & $\begin{array}{l}-0.054 \\
(-0.11)\end{array}$ & $\begin{array}{l}0.050 \\
(0.12)\end{array}$ & $\begin{array}{l}-0.206 \\
(-1.45)\end{array}$ \\
\hline Firm years (firms) & & $5,640(1,296)$ & $5,482(1,287)$ & $2,634(869)$ & $5,640(1,296)$ & $5,482(1,287)$ & $2,634(869)$ \\
\hline Adjusted R-squared & & 0.1671 & 0.1716 & 0.3781 & 0.1643 & 0.1693 & 0.3740 \\
\hline F-value & & $3.01 * * *$ & $2.68 * * *$ & & $3.01 * * * *$ & $2.68 * * *$ & \\
\hline Wald Chi-squared & & & & $109.67 * * *$ & & & $74.07 * * *$ \\
\hline \multicolumn{8}{|c|}{ Panel B Changes in total compensation } \\
\hline Dependent variable & Predicted & $\begin{array}{c}\triangle \mathrm{COMB} \\
\mathrm{COMP} \\
(1)\end{array}$ & $\begin{array}{l}\triangle \mathrm{NED} \\
\mathrm{COMP} \\
(2)\end{array}$ & $\begin{array}{c}\Delta \text { CHAIR } \\
\text { COMP } \\
(3)\end{array}$ & $\begin{array}{c}\triangle \mathrm{COMB} \\
\mathrm{COMP} \\
(4)\end{array}$ & $\begin{array}{c}\triangle \mathrm{NED} \\
\mathrm{COMP} \\
(5)\end{array}$ & $\begin{array}{c}\Delta \text { CHAIR } \\
\text { COMP } \\
(6)\end{array}$ \\
\hline MKTADJRET $_{t-1}$ & $?$ & $\begin{array}{c}0.090 * * * \\
(3.52)\end{array}$ & $\begin{array}{c}0.089 * * * \\
(3.26)\end{array}$ & $\begin{array}{c}0.069 * * * \\
(4.80)\end{array}$ & - & - & - \\
\hline $\operatorname{IAROA}_{t-1}$ & ? & - & - & - & $\begin{array}{l}0.067 \\
(0.84)\end{array}$ & $\begin{array}{l}0.035 \\
(0.39)\end{array}$ & $\begin{array}{l}-0.011 \\
(-0.33)\end{array}$ \\
\hline$\triangle$ ASSETS $_{t-1}$ & + & $\begin{array}{l}0.025 \\
(0.74)\end{array}$ & $\begin{array}{c}0.38 \\
(1.09)\end{array}$ & $\begin{array}{l}-0.008 \\
(-0.61)\end{array}$ & $\begin{array}{c}0.044 * \\
(1.86)\end{array}$ & $\begin{array}{c}0.055 * * \\
(2.17)\end{array}$ & $\begin{array}{l}0.012 \\
(1.01)\end{array}$ \\
\hline Constant & & $\begin{array}{l}0.061 \\
(0.08)\end{array}$ & $\begin{array}{l}0.129 \\
(0.21)\end{array}$ & $\begin{array}{l}-0.309 \\
(-1.18)\end{array}$ & $\begin{array}{l}0.100 \\
(0.13)\end{array}$ & $\begin{array}{l}0.159 \\
(0.27)\end{array}$ & $\begin{array}{l}-0.314 \\
(-1.19)\end{array}$ \\
\hline Firm years (firms) & & $5,640(1,296)$ & $5,482(1,287)$ & $2,634(869)$ & $5,640(1,296)$ & $5,482(1,287)$ & $2,634(869)$ \\
\hline Adjusted R-squared & & 0.1656 & 0.1706 & 0.3207 & 0.1626 & 0.1681 & 0.3170 \\
\hline F-value & & $4.29 * * *$ & $3.32 * * *$ & & $3.83 * * *$ & $2.68 * * *$ & \\
\hline Wald Chi-squared & & & & $90.28 * * *$ & & & $66.73 * * *$ \\
\hline
\end{tabular}


